\title{
A monumentalidade discursiva no budismo indo-nepalês: uma estratigrafia das fontes escritas e iconográficas presentes no Gunakāraṇ̣̂yūhasūtra
}

\author{
Cibele Elisa Viegas Aldrovandi*
}

\begin{abstract}
ALDROVANDI, C.E.V. A monumentalidade discursiva no budismo indo-nepalês: uma estratigrafia das fontes escritas e iconográficas presentes no Guṇakāraṇ̣̂yūhasūtra $\mathbf{R}$. Museu Arq. Etn., São Paulo, n. 22: 3-30, 2012.
\end{abstract}

Resumo: Este artigo apresenta os resultados do primeiro ano de pesquisa sobre um manuscrito sânscrito budista contendo o Guṇakāraṇdavyūhasūtra. Esse sūtra, de origem indo-nepalesa, vem sendo investigado por meio de uma abordagem interdisciplinar, conjugando as áreas conexas e com base nos fundamentos teórico-metodológicos da linguística, da arqueologia e da história da arte. A pesquisa é centrada na análise da estratigrafia das fontes escritas e iconográficas associadas à obra, de sorte a compreender as estratégias sociorreligiosas que permearam sua gênese narrativa no novo milieu. Os resultados apontam para uma monumentalização do sūtra original Mahāyāna que, ao ser reelaborado no contexto do budismo esotérico nepalês, adquiriu uma transcendência narrativa que o transformou em um maṇdala textual, uma dimensão formal diretamente associada a esses esquemas geométricos sagrados que permeiam a paisagem cultural nepalesa.

Palavras-chaves: Budismo, Índia, Nepal, Gunakārandavyūhasūtra, Avalokiteśvara, Iconografia, Monumentalidade, Maṇdala textual.

\section{Introdução}<smiles>C1=CCCCC=1</smiles>
ponto de partida e objeto fulcral de análise deste artigo é o manuscrito contendo o Gunakārandavyūhasūtra, atualmente sob a guarda do Museu de Arqueologia e Etnologia - MAE/USP. Esse manuscrito é parte de uma pequena coleção de obras asiáticas

(*) Pós-Doutorado pelo Departamento de Letras Clássicas e Vernáculas, Área de Sânscrito, FFLCH-USP. <aldrovan@ yahoo.com> pertencente ao extinto Instituto Cultural Banco Santos [01012]. A existência desse manuscrito em uma instituição de pesquisa brasileira é algo certamente raro e, portanto, ele vem sendo pesquisado em toda sua propriedade ao longo deste projeto inédito em nosso país.

Esse sūtra budista está sendo investigado por meio de uma abordagem interdisciplinar, conjugando as áreas conexas e com base nos fundamentos teórico-metodológicos da linguística, da arqueologia e da história da arte. A pesquisa empreendida vem favorecendo significativamen- 
A monumentalidade discursiva no budismo indo-nepalês: uma estratigrafia das fontes escritas e iconográficas presentes no Guṇakāraṇdavyūhasūtra

R. Museu Arq. Etn., São Paulo, n. 22, p. 3-30, 2012.

te a análise e a interpretação das relações dialógicas estabelecidas entre as fontes textuais e iconográficas presentes no Guṇakārandavyūhasūtra, de sorte a recuperar e evidenciar o desenvolvimento estratigráfico dos discursos intertextual e intericônico associados a essas fontes e, assim, compreender as estratégias sociorreligiosas que permearam sua gênese narrativa.

Levantamento das informações sobre o manuscrito MAE/USP

O manuscrito contendo o [Āryāvalokiteśvara] Guṇakāraṇdavyūhasūtra [GKV] - "Sūtra da explicação do conjunto das qualidades [do Nobre Avalokiteśvara]" - é um original nepalês produzido em folha de palmeira (parṇa ou talāpātra), datado de 1807. Ele possui 223 fólios pintados na cor índigo (nīlapātra) com desgastes variados e em escrita newāri (nepalesa antiga) em tinta dourada em ambos os lados ( $a$ e $b$ ), cada um deles com cinco linhas e uma camada de verniz, conforme o padrão dos manuscritos nepaleses (Fig. 1). $\mathrm{O}$ formato dos fólios é retangular, medindo aproximadamente 39,2 X 8 cm. Diferente do usual, os fólios não foram perfurados para a passagem do cordão que costuma manter as folhas em ordem (v. Murthy 1996: 27-54, 103), embora as áreas para a perfuração, simétricas, tenham sido previstas entre a segunda e a quarta linhas de cada fólio. Cada fólio é numerado na lateral direita do texto, em seu lado posterior (reverso).

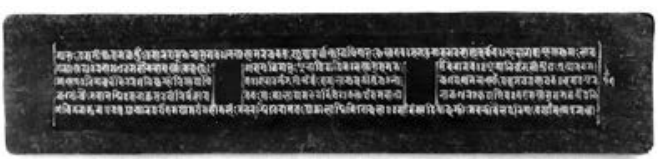

Fig. 1. Fólio 17b do Guṇakāraṇdavyūhasūtra MAE/USP (Fonte: acervo pessoal Aldrovandi 2011).

A escrita nepalesa é derivada do brāhmī assim como o devanāgarī (v. Rajbanshi 1974: 120); no manuscrito MAE/USP a metade dos versos é marcada por um único danda e o final por um duplo danda. O final de um capítulo é numerado entre dois danda duplos, apresenta o nome do capítulo e é marcado por um desenho ou símbolo específico (v. Murthy 1996: 106-110). Alguns fólios apresentam correções nas margens (marginalia), acrescentadas acima do texto original, geralmente em tinta amarela (e.g. fólios 6b, 9a, 9b, 10a, 10b, 72b). Por vezes, partes das palavras estão ilegíveis.

O primeiro fólio possui a única pintura miniatura do manuscrito, com a figura de Avalokiteśvara (Fig. 2), em sua forma Padmapāṇi ("Aquele que segura o lótus"). A imagem do Bodhisattva aparece segurando o lótus com a mão esquerda enquanto a direita está em varadamudrā. Ele está em pé sobre um lótus, possui uma auréola rosada e uma mandorla laranja com finos raios amarelos; ao seu redor estão oito botões de lótus sobre um fundo verde azulado. A veste inferior é um paridhāna vermelho com desenhos amarelos e um uttariya azul e esvoaçante recobre os ombros do Bodhisattva (Fig. 3).

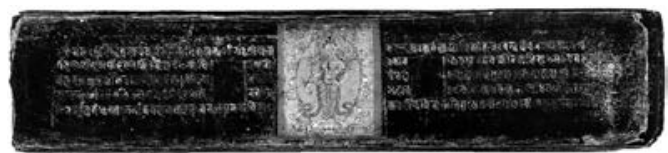

Fig. 2. Fólio 1a, com pintura miniatura e escrita com desgastes (Fonte: acervo pessoal Aldrovandi 2011).

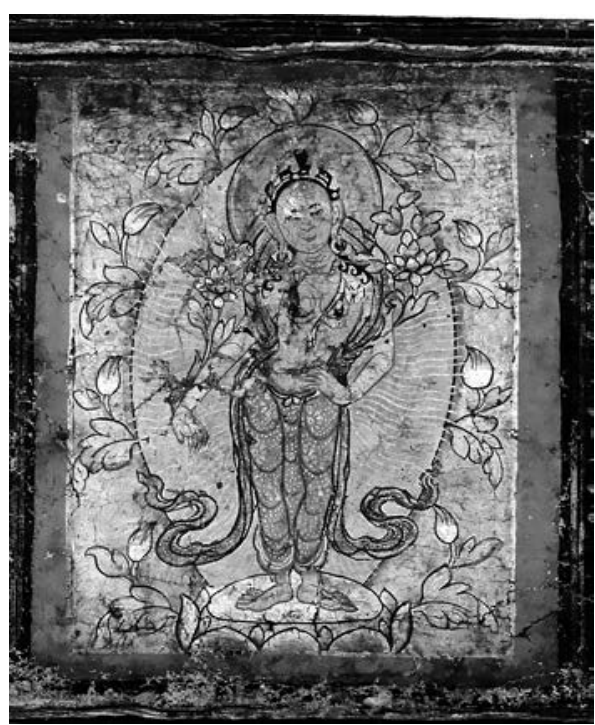

Fig. 3. Detalhe do fólio 1a, com pintura miniatura do Bodhisattva Avalokiteśvara.

(Fonte: acervo pessoal Aldrovandi 2011). 
O manuscrito é protegido por duas capas de metal, confeccionadas em cobre dourado na técnica repoussé e medindo aproximadamente $39,5 \times 8,3 \mathrm{~cm}$, poucos milímetros maiores que os fólios (Fig. 4). A parte interna das capas, em madeira, recebeu uma camada de tinta azul celeste e se encontra desgastada. Em relação à iconografia, a capa frontal apresenta uma moldura de pétalas de lótus ao redor de uma paisagem montanhosa, com nuvens estilizadas e motivos florais laterais típicos da arte himalaica; na porção interna, três nichos-santuários com molduras florais e um kirtimukha no topo abrigam, no centro, uma imagem do Buda Śākyamuni sentado em bhumiparśamūdra e, nas laterais, as imagens do Bodhisattva Avalokiteśvara, em sua forma Sadākșari com quatro braços, e do Bodhisattva Mañjuśrī com dois braços, ambos sentados. A capa posterior possui o mesmo tipo de moldura com pétalas de lótus e, no centro, três lótus de oito pétalas estão entre a decoração floral. O douramento está desgastado em algumas regiões e há vestígios de policromia vermelha ou, mais provavelmente, kumkum em certas áreas das imagens, que são um indício de origem ritual.

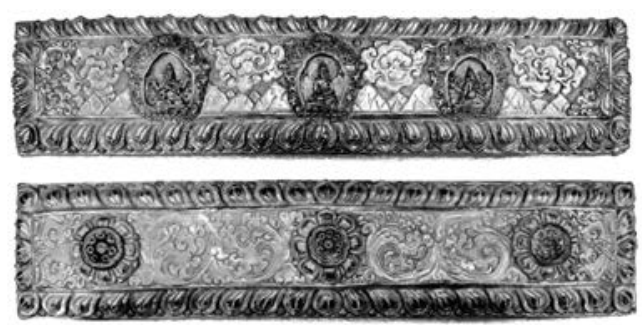

Fig. 4. Capas do manuscrito contendo o Guñakāranḍ̂vyūhasūtra

(Fonte: acervo pessoal Aldrovandi 2011).

Registro fotográfico e organização do manuscrito

O registro fotográfico de todo o manuscrito para o estudo sistemático do texto foi realizado em câmeras de 8.0 megapixels (fevereiro de 2011) e de 16.1 megapixels (agosto de 2011) na Curadoria do MAE-USP. Além disso, também foi realizada a organização dos fólios do manuscrito
[01012], pois eles estavam acondicionados de modo desordenado, uma vez que não possuem o cordão para mantê-los na sequência correta.

Após o primeiro acesso ao manuscrito para registro fotográfico (fevereiro de 2011), foi verificado, durante a decifração do alfabeto e o início da transliteração do texto, que os fólios encontravam-se completamente desordenados e, em muitos casos, invertidos. Assim, no segundo acesso ao material original, para novo registro fotográfico com uma câmera de maior definição, foi proposta e aprovada, pela direção do MAE-USP, a organização da numeração sequencial dos fólios do manuscrito para posterior guarda do material em reserva técnica. O fólio 1a (com iconografia), por exemplo, encontrava-se no meio do manuscrito (v. Fig. 5).

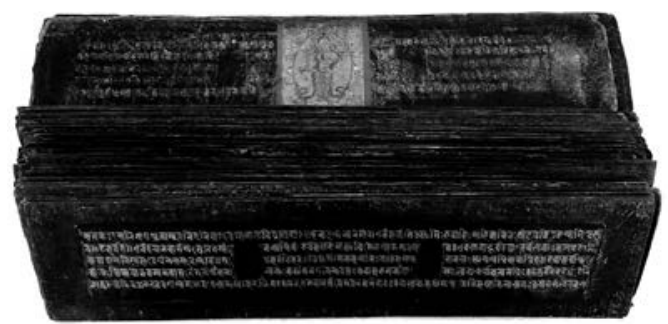

Fig. 5. Os fólios desordenados do manuscrito e o fólio 1a com iconografia de Avalokiteśvara entre os demais (Fonte: acervo pessoal Aldrovandi 2011).

Assim, os fólios foram organizados pela numeração sequencial presente na lateral direita de seu lado "b". Após o término da organização, os fólios foram fotografados e, em seguida, preparados para o acondicionamento em material de $\mathrm{Ph}$ neutro e posterior armazenamento em área de reserva técnica (Fig. 6).

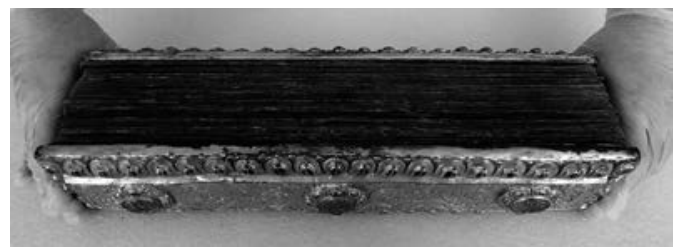

Fig. 6. O manuscrito após a organização sequencial dos fólios entre suas capas originais (Fonte: acervo pessoal Aldrovandi 2011). 
A monumentalidade discursiva no budismo indo-nepalês: uma estratigrafia das fontes escritas e iconográficas presentes no Guṇakāraṇ̣̂yūhasūtra

R. Museu Arq. Etn., São Paulo, n. 22, p. 3-30, 2012.

\section{O Guṇakārạ̣ḍavyūhasūtra}

Os primeiros exemplares do Gunakāraṇdavyūhasūtra surgiram no Nepal durante o século XV d.C., época em que a produção de manuscritos budistas em sânscrito havia terminado em outras regiões do sul da Ásia. Com o declínio do budismo em território indiano, principalmente após o século XII d.C., o vasto corpus de textos narrativos, rituais, doutrinários e disciplinares que haviam sido compilados, comentados e meticulosamente preservados nas universidades monásticas budistas em Magadha e Bihar foram transferidos e preservados nos monastérios nepaleses do vale do Katmandu, que se tornaram repositórios e transmissores desse conhecimento de tradição sânscrita.

No século XV d.C., a mera preservação dessa tradição textual indiana não era mais suficiente para manter a vitalidade e a autoridade do budismo sânscrito no Nepal. Devido às mudanças na ordem política e social ocorridas nas principais cidades-estado nepalesas - Lalitpur, Banepa, Bhaktapur e Kantipur -, a autoridade da tradição budista indo-nepalesa foi posta em cheque (v. Locke 1980, 1985; Gellner 1992; Lewis 1996). Ao longo de várias décadas, novos textos surgiram, geralmente modelados a partir de textos célebres mais antigos. Os budistas nepaleses eram grandes apreciadores de histórias e exímios ritualistas, por isso, esses textos tendiam a ser versões revisadas e ampliadas de coleções mais antigas com histórias didáticas e inspiradoras sobre as aventuras de grandes Bodhisattvas e as realizações dos Budas em suas vidas anteriores.

Nesse sentido, o GKV se insere entre os últimos sūtra budistas compostos em sânscrito e seus autores foram sacerdotes Vajrayāna que viveram em monastérios no Nepal do século XV d.C., herdeiros da grande tradição sânscrita budista (cf. T.-Douglas 2006: 1).

\section{O sânscrito híbrido budista}

O sânscrito utilizado no manuscrito MAE/ USP não é o clássico e sim uma forma híbrida budista já associada a elementos newāri ou nepāli (v. Murthy 1996: 15), uma língua sino-tibetana falada pelos habitantes do Vale do Katmandu. Em relação aos manuscritos GKV de modo geral, T.-Douglas (2006: 25) observou tratar-se de um sânscrito que apresenta um grau de mudança linguística em direção a um dialeto "nepalizado" do sânscrito clássico, que o estudioso utilizou como elemento diagnóstico para datação e identificação desses textos.

O sânscrito híbrido budista é a língua em que a maioria dos textos do norte da Índia foi composta, baseada em um antigo vernáculo do indiano médio que foi fortemente influenciado pelo sânscrito. Por isso, muitos produtos dessa tradição foram geralmente chamados de sânscrito, sem uma qualificação mais precisa (v. Edgerton 1953). Como foi observado pelo estudioso:

a extensão da sanscritização varia muito de acordo com o período, algumas vezes, ela varia até mesmo dentro da própria obra. A maioria das obras em sânscrito híbrido budista é composta em um misto de prosa e verso. Em alguns casos, o grau de sanscritização é equivalente, na prosa e em verso, em outros, a prosa é aparentemente mais sanscritizada, a tal ponto que sua fonologia e morfologia parecem quase sânscrito padrão. Mesmo assim, a prosa revela uma base do indiano médio, primeiro pelo fato de apresentar ocasionalmente formas não sânscritas; e, segundo, pelo fato de o seu vocabulário ser tão indiano médio quanto aquele dos versos. Isto é, contém um grande número de palavras que nunca aparecem, ou não aparecem com o mesmo significado que no sânscrito padrão. São palavras dos budistas que são parte de uma tradição do indiano médio, embora possam ter uma aparência sanscritizada. (...) Há evidências que mostram que, morfologicamente, bem como ortograficamente, os textos sânscritos híbridos budistas passaram por uma crescente adaptação em direção às normas sânscritas ao longo de sua transmissão pela tradição (Edgerton 1953: 5-6). 
Nesse sentido, o manuscrito aqui pesquisado é um exemplar tardio, que passou por vários estágios de cópia configurando aquilo que Murthy (1996: 111-13, 122-32) chamou de texto transmitido e apresentando, muitas vezes, divergências na forma de acréscimos, faltas, substituições ou trocas, de letras, palavras, frases ou parágrafos. As disparidades são atribuídas por esse estudioso às idiossincrasias do próprio copista, que estabelece a fidelidade, ou a disparidade, da cópia e dos exemplares seguintes.

A maioria das variantes morfológicas e aquelas que se devem a erros dos copistas no sânscrito híbrido budista foram analisadas por Brough (1954) sobre a obra de Edgerton (1953). T.-Douglas (2006: 25-7) também apresentou observações interessantes sobre as mudanças linguísticas nos chamados Textos Guirlanda, dos quais faz parte o GKV. Para esse pesquisador, essas formas tendem a ser elementos gramaticais que, embora incorretas e, por vezes, ininteligíveis em termos do sânscrito clássico, têm uma boa explicação quando compreendidas em termos da gramática do newāri. "A língua dos sūtra budistas newār apresenta divergências do padrão clássico. Em alguns casos o processo de derivação é tão acentuado que chega à incompreensibilidade. A ortografia é aleatória, mas a sintaxe também mudou consideravelmente" (T.-Douglas 2006: 26). Assim, como lembrou Edgerton (1953: 11), "em alguns casos, as camadas cronológicas no mesmo livro são mais facilmente detectáveis pelos critérios estilísticos ou métricos que pelos morfológicos ou ortográficos".

Em relação aos erros fonéticos, visuais e auditivos encontrados de modo recorrente, apresentamos abaixo aqueles que foram observados com mais frequência durante a tradução do capítulo 2 e análise global do GKV (MAE/ USP), comparados com as observações de Edgerton (1953), Brough (1954) e T.-Douglas (2006: 25-30).

Entre as vogais breves e longas, o $i$ e o $\bar{i}$ são sempre confundidos. Por exemplo, no GKV, o nome do Bodhisattva interlocutor do Buda é Sarvanivaraṇavișkambhin, mas em Edgerton (1953) e no Kārandavyūhasūtra, temos: Sarvanīvaraṇaviṣkambhin. $U$ e $\bar{u}$ aparecem também confundidos, e na escrita newāri tardia o $\bar{u}$ longo raramente aparece diferenciado (cf. T.-Douglas 2006: 26). Em alguns casos, o e $\bar{a}$ são igualmente confundidos, geralmente ambos representados como ā. De acordo com Rajbanshi (1974: 120), no Nepal, após o período Licchavi, o alfabeto devanāgarì mudou e passou a ser chamado newāri antigo, nessa época, as vogais sofreram igualmente modificações. $\mathrm{O}$ anusvāra (h) é frequentemente omitido, ou aparece no final da frase ou na metade do verso, assim como o final $-m$.

Entre as consoantes, o ș transformado em kh deriva de uma mudança fonética. $s, s, s$ e $s$, são praticamente indistinguíveis em newāri e parecem intercambiáveis, sendo que entre ś e ș, não há distinção na pronúncia; já a permuta $s ́$ e $s$ é menos comum. Outros fonemas que sofrem alteração: ra e la, mesmo em palavras conhecidas como vihāra, mas la nunca substitui $r a$ antes de outra consoante, o que sugere que a confusão auditiva ocorre apenas quando a semivogal aparece sozinha, como bem observado por T.-Douglas (2006: 27). Em certos casos, a troca das consoantes ra e na constitui um erro visual típico da escrita newāri, observada apenas nos manuscritos mais tardios. Os encontros consonânticos tya e bhya têm grafia semelhante em newāri. A substituição de śra por śu é recorrente em śraddhā > śuddhā. Menos frequente é a troca de ja para ya. A duplicação de consoantes algumas vezes ocorre após $r$, dharma $>$ dharm$m a$; além da duplicação, pode haver omissão de outras letras, e.g. ākarṇya > ākarṇnya > ākarṇna, em que o $y$ desaparece. Pode ocorrer também a omissão de uma consoante dupla: $d d h>d h$, principalmente na palavra saddharma $<>$ sadharma $<>$ sadharmma $<>$ saddharmma, que aparece nas quatro formas possíveis ao longo do GKV (MAE/USP).

Talvez a mudança fonética mais evidente e recorrente seja a troca do $b$ pelo $v$, em todas as vezes que é grafado bodhisattva > vodhisattva. A transmissão do sūtra original, durante a realização da nova cópia, era feita oralmente e não visualmente, o que explica muitos erros fonéticos. Um copista ou editor consciente da ortografia correta do sânscrito possivelmente a 
A monumentalidade discursiva no budismo indo-nepalês: uma estratigrafia das fontes escritas e iconográficas presentes no Guṇakāraṇdavyūhasūtra

R. Museu Arq. Etn., São Paulo, n. 22, p. 3-30, 2012.

restaurava; nesse sentido, quando são encontrados certos erros aparentemente ortográficos de modo consistentemente recorrente em manuscritos de boa qualidade, deve-se suspeitar que se trata de algo mais que um simples erro de soletração (cf. Douglas 2006: 28). O exemplo de mudança do ș para kh ocorre também nos encontros consonantais (cf. Handurukande 1967: xiii, n. 48, apud Douglas 2006: 29), tal alteração seria possivelmente um elemento de alguns dialetos indo-arianos, e não derivada das línguas tibeto-birmanesas do Himalaia, tratando-se portanto de uma mudança fonética e não um erro de escrita.

Em relação às declinações, T.-Douglas (2006: 29) menciona o uso do instrumental com formas verbais ativas, bem como o uso invertido e inapropriado do nominativo no lugar do acusativo. Da mesma forma, esse estudioso observa trocas entre tempos verbais em frases narrativas no passado imperfeito e frases no modo optativo. De acordo com Takahata (1954: xix, apud Douglas 2006: 29), essa mudança na forma verbal pode ter ocorrido para a acomodação da métrica. Observa-se também o uso recorrente de absolutivos em -tvā. A decisão de usar -ya ou -tvā, dependeria da raíz verbal simples ou prefixada (e.g. $\sqrt{\mathrm{na}}(\mathrm{m})-\mathrm{t} v \bar{a}$ 'tendo reverenciado' e prav nam-ya 'tendo reverenciado muito'), o que é considerado um resquício de um elemento indo-ariano médio, dos prácritos antigos (v. Edgerton 1953; T.-Douglas 2006: 29).

Como observou T.-Douglas (2006: 32), nos colofões dos manuscritos GKV, o título sempre aparece como Āryāvalokiteśvaraguna kārandavyūhasūtra, mas no Nepal ele é geralmente referido apenas pelo nome mais breve, Gunakāranḍavyūhasūtra.

O colofão do manuscrito MAE/USP, por sua vez, foi escrito em uma forma híbrida e incorreta de sânscrito e nepalês, apresentando trechos corrompidos. Ali, está mencionado que a cópia foi finalizada numa quinta-feira, o décimo terceiro dia do quarto obscuro (lua minguante) do mês Aśvin (setembro-outubro), na fase lunar Hasta, de 1807 (NS 927). O copista (lipikāra) era o vajrācārya (sacerdote tântrico hereditário) chamado Śrī Guṇa Om̉ Ta[r]ūna, do He[m]ava[r]ṇamahāvihara (Kwa Bahal), o Templo Dourado no norte de Patan, fundado em 1409, conhecido como o mais próspero e maior monastério em número de discípulos (v. Gellner 1992: 236).

De forma semelhante, a escrita também sofreu influência regional e possui diferenças e adaptações do devanāgarī [e.g. as vogais: $i(\widetilde{\Upsilon})$ e $\overline{1}(\widetilde{\swarrow}()$ ]. Por isso, no início dos trabalhos foi realizada uma decifração dos caracteres e preparada uma tabela detalhada para auxiliar posteriormente na transliteração do texto.

\section{O manuscrito como relíquia}

No contexto budista, a cópia de manuscritos era considerada um ato meritório, que auxiliava no caminho da budeidade. Tanto o copista quanto o indivíduo a patrocinar sua produção adquiriam méritos, uma crença que ainda existe atualmente. Um aspecto relevante sobre essa questão está associado à tradução do título do GKV, proposta por T.-Douglas (2006: 1) como o "conjunto de relicários de bambu sobre as qualidades [de Avalokiteśvara]". Como observou esse pesquisador, embora a palavra kāraṇda não esteja listada como "relicário" em nenhum léxico padrão, o termo significa algo confeccionado em bambu, mais especificamente, uma pequena caixa para livros. Existe, segundo ele, um termo singalês semelhante, kāranduva, que significa relicário (cf. T. Douglas 2006: 32). O fato de o termo kāranda estar associado a relicários é interessante, pois remete à questão de os textos serem, eles próprios, relíquias sagradas do budismo.

As fontes textuais da época de Aśoka mencionam três tipos de relíquias budistas: 1 . śarīraka - as relíquias corpóreas do Buda, após sua cremação (ossos, dentes, cabelo); 2. paribhogaka - os objetos que lhe pertenceram (vestes, tigela, mantos) ou os locais visitados pelo Buda (que inclui a árvore bodhi); 3. uddeśaka - os ensinamentos (inscrições) e as lembranças do Buda, isto é, qualquer coisa que fizesse lembrar a natureza ou presença do Buda (suas pegadas, sua sombra, as representações visuais). Esta terceira categoria é também classificada por alguns estudiosos como dharmaśarīra ("relíquias 
do dharma"), que inclui os sūtra (tratados filosóficos complexos sobre a sabedoria da não substancialidade ou vacuidade apresentados de forma completa ou limitados aos versos), ou as dhāranī ("fórmulas de encantamento"), ou qualquer tipo de registro dos ensinamentos do Buda (v. Bentor 1994:16; Strong 2004: 8).

A inclusão do dharma - mais literalmente dos textos doutrinários propriamente ditos - como uma categoria de relíquias é bastante significativa (v. Wallis 2001), uma vez que as fontes textuais narram que, em seus últimos momentos de vida, ao ser inquirido por seu discípulo Ānanda sobre quem deveria substituí-lo após sua partida, o Buda teria dito que eram seus ensinamentos, o seu dharma (cf. Bareau 1970-71, 2: 136-37).

As fontes textuais corroboram a crença de que o dharma podia atuar como um substituto do mestre ausente. Nesse mesmo sentido, as relíquias budistas serviam de um modo geral como suas substitutas. De fato, no contexto integral da tradição budista, tanto as relíquias do dharma quanto as relíquias corpóreas foram utilizadas como representantes do Buda. Assim, a devoção às relíquias incluía a adoração dos estupas e das imagens, mencionada nos cânones budistas entre o terceiro tipo (as lembranças e representações). O ritual de consagração de monumentos e esculturas é observado na história do budismo desde seus primórdios. Nele, as relíquias do Buda e, mais tarde, de monges célebres eram consideradas, e ainda o são até o presente, como imbuidas de vida (v. Schopen 1987, 1997; Aldrovandi 2008: 169). Elas eram consagradas justamente pela inserção em seu interior de uma relíquia corpórea (p. ex.: um pedaço de osso), ou de uma relíquia textual (p. ex.: um verso escrito de um ensinamento do Buda), ou mesmo ambas.

Como observou Strong (2004: 9), em termos fenomenológicos e - caberia acrescentar - também semióticos, "ossos" e "livros" podiam funcionar de modo parecido e cumprir papéis semelhantes. A existência de uma prática de produção de "corpos textuais" ou "relíquias do dharma" - dharmaśarìra - é atestada nas fontes textuais. $\mathrm{O}$ peregrino chinês Hsuan-Tsang (c.
602-664 d.C.) menciona, em sua narrativa, um piedoso devoto leigo de Rājagṛha - a primeira capital de Magadha - que, enquanto orava, manufaturava essas relíquias (chin.: fa sheli), miniaturas de estupas, que ele depois consagrava inserindo em seu interior um verso escrito de um sūtra (cf. Li 1996: 266, apud Strong 2004:10). Episódios semelhantes recorrem no cânone chinês, em cujo contexto os versos são chamados de "corpo do dharma" do Buda.

Outro elemento importante, de caráter arqueológico, a corroborar tais fontes refere-se ao tratamento dos textos budistas inscritos em casca de bétula (Betula papyrifera), encontrados junto aos grandes estupas dos monastérios em Gandhāra - no noroeste da Índia antiga, enterrados diretamente em potes de cerâmica, semelhantes aos vasos utilizados para sepultar os restos mortais dos monges cremados (Salomon 1999: 79-81). Tais vestígios são um indício de que um tratamento semelhante era dado tanto aos textos sagrados antigos (que não estavam mais em uso) quanto às relíquias corpóreas.

\section{A iconografia associada ao Guṇakāraṇḍavyūhasūtra}

O protagonista da narrativa do GKV é o Bodhisattva Avalokiteśvara - "aquele capaz de olhar abaixo [do paraíso de Amitābha]” -, cujas formas de representação são extremamente amplas e variadas. Nesta fase da pesquisa, restringimos a análise às representações que aparecem citadas entre os epítetos no Kāraṇdavyūha [KV] e no Gunakārandavyūhasūtra [GKV].

Embora Avalokiteśvara possua muitos epítetos, todos associam-no à Verdade, ao Amor, à Compaixão, à Sabedoria e à Iluminação, assim como ao seu voto de salvar todos os seres sencientes do samsāra pela grande compaixão e capacidade infinita que possui. Como foi descrito:

Ele é o olhar compassivo do Buda, distribuído por todos os pontos do espaço para salvar as criaturas sofredoras; ele é o olhar divino, que inspeciona o mundo a partir do Paraíso Tușita, para encontrar o lugar mais apropriado para realizar sua 
A monumentalidade discursiva no budismo indo-nepalês: uma estratigrafia das fontes escritas e iconográficas presentes no Guṇakāraṇ̣̂yūhasūtra

R. Museu Arq. Etn., São Paulo, n. 22, p. 3-30, 2012.

missão de redenção das faltas e dores; é o olhar voltado para baixo para explorar os infernos e derramar o consolo de sua piedade cada vez que os olhos se viram; assim o poeta anônimo do Kāraṇdavyūha o exalta" (Tucci 1923: 625).

O capítulo 2 do GKV, traduzido integralmente durante o primeiro ano desta pesquisa, contém o excerto com o Louvor de Yama, no qual é citada uma série de epítetos de Avalokiteśvara. Entre eles estão: Lokanātha [4, 178, 333, 367]; Lokeśa [17, 159, 165]; Dharmarāja [v. 24, 369]; Āryāvalokiteśvara [151]; Karunāmaya [153]; Lokeśvara [168, 185, 206, 284, 345, 363, 365]; Āryāvalokiteśa [289]; Śatasahasrahasta [293]; Amoghapāśa [321]. Alguns deles diferem daqueles presentes no KV. A presença e/ou ausência desses epítetos na obra mais tardia, vem sendo objeto de uma análise detalhada.

No cânone budista existe uma série de seis Lokeśvara listados, que são considerados associados ao sadākșarividyā (cf. Chandra 2000: 428), o mantra de seis sílabas apresentado no KV e no GKV. São eles: 1. Āryāvalokiteśvara - o Nobre Avalokiteśvara; 2. Ekādaśamukha Avalokiteśvara - com onze cabeças; 3. Sahasrabhuja Avalokiteśvara - com mil braços; 4. Hayagrīva Avalokiteśvara - com cabeça de cavalo; 5. Cintāmanicakra Avalokiteśvara que possui a joia cintāmaṇi, outorgadora de desejos; 6. Amoghapāśa Avalokiteśvara - com o laço infalível.

No repertório iconográfico antigo e medieval suas formas são igualmente múltiplas e estão disseminadas por toda a Ásia. O Bodhisattva aparece representado como Padmapāṇi, Sadākșari, Ekādaśamukha, Lokanātha, Lokeśvara, Simhanāda, Sahasrabhuja-Sahasranetra, Amoghapāśa, Cintāmaṇi, Āryāvalokiteśvara, Jñanadhatu, Nīlakaṇța, Khasarpaṇa, Macchendranath, Harihariharivahana-Lokeśvara e na Litania de Avalokiteśvara, entre outros.

A propósito da origem da palavra Avalokiteśvara, discutida por Chandra (2000: 424), o estudioso propõe Avalokita, como forma abreviada de Avalokita-svara e a teonímia mais antiga da forma posterior de Avalokiteśvara, que serve para os diferentes Lokeśvara ou Lokanātha, incluindo Padmapāni, Khasarpaṇa, Ekādaśamukha e para o Sadakșarī tibetano. A palavra Avalokita aparece no Bodhicaryāvatāra [BCA 2.51] de Śāntideva (século VII d.C.) e no Mahāvastu [2.257.13, 259.4], e como um sūtra no colofões [293.15, 397.7]. No Avalokana(nā) sūtra é citado como um Bodhisattva da categoria de um Tathāgatha ["Avalokitas tu Buddhe"]. No BCA [2.49.52], ele é o terceiro dos cinco Bodhisattvas (bodhisattvagana): Samantabhadra, Mañjughoșa, Avalokitanātha, Ākāśagarbha e Kșitigarbha.

Chandra (2000: 425) traduz Avalokita como "contemplação, visualização" e cita o comentário chinês do Kārunikarājasūtra, no qual o significado seria "o bhūta (real) lakșaṇa (caráter) dos Budas como objetos de vipasyanā". Edgerton (1953) traduz vipasyanā como "discernimento, compreensão correta, inteligência, visão, contemplação”. A forma Avalokitasvara teria precedido a atual e ocorre cinco vezes num fólio do $24^{\circ}$ capítulo de uma versão chinesa do Saddharmapuṇ̣arīkasūtra, o que não poderia ser um mero erro do copista. O estudioso relaciona -svara a "som", e o significado do nome “àquele que ouve os gritos do mundo”. Em seguida, associa Avalokitasvara a Brāhma, uma versão budista do deus védico-bramânico que pediu a Śākyamuni para pregar o Dharma. Ele seria um substrato do Dharma, ou "uma epifania de Brāhma” (Chandra 2000: 444), daí sua proeminência, primeiro ao lado de Amitābha e, depois, de forma independente.

Se, na arte de Gandhāra e de Mathurā, Brāhma e Indra aparecem de modo recorrente ao lado do Buda Śākyamuni, com o crescimento dos aspectos transcendentais do budismo Mahāyāna, Śākyamuni gradualmente foi substituído por Amitābha, ladeado por Avalokiteśvara e Mahāsthāmaprāpta (Vajrapāni), o primeiro segura o lótus e o segundo, o vajra, significando o discernimento e o caminho - prajña e upāya. No Saddharmapuṇụīīasūtra [24.28], Avalokiteśvara é chamado Lokeśvararājanayaka, "aquele cujo senhor é Lokeśvararāja", 
isto é, um epíteto de Amitābha. Além disso, Brāhma é aquele que tem a visão daquilo que está contido nos mantras, o símbolo da palavra revelada (ele segura os quatro Vedas nas mãos). Avalokiteśvara, por sua vez, como Avalokita (vidente) -svara (palavra), possui um simbolismo semelhante. No Amitāyurdhyānasūtra [2.259b], Avalokitasvara é o grande vidyādhipati e possui centenas de mantras (v. Chandra 2000: 426 7). Em Gandhāra, o nome Avalokiteśvara foi encontrado na inscrição de uma escultura. Para esse estudioso, tratou-se de uma assimilação entre Avalokitasvara, o acólito de Amitābha, com divindades populares locais (Lokeśvaras ou Lokanāthas) no sempre crescente panteão budista, reforçando e ampliando sua disseminação - assim como, em seguida, divindades como Hayagrīva e Nīlakanțha foram absorvidos e se tornaram epítetos e formas de Avalokiteśvara. Para Chandra (2000: 427), uma dhāraṇī de Avalokiteśvara com mil braços era, originalmente, um hino a Nỉlakanțha que, mais tarde, foi assimilado. Nesse sentido, Avalokiteśvara seria "um termo fluido e genérico criado verbalmente em um magma linguístico, aplicado com o tempo ao bodhisattva com nomes definidos" (Chandra 2000: 464).

$\mathrm{O}$ misericordioso Bodhisattva é descrito de modo recorrente nas fontes textuais. Ele é citado no Mahāvastu-avadāna [2.294], um texto Mahāsāṇghika datado por volta do século III a.C., no qual é dito que "o Bhagavān que toma a forma de um bodhisattva, cujo dever é olhar ao redor (avalokita) para instruir as pessoas e para o bem e felicidade constante" (cf. Bhattacharyya 1958:143). Há uma série de textos traduzidos para o chinês que o descrevem, como o Sukhāvativyūhasūtra longo, traduzido por Lokakșema entre 147-186 d.C. (v. Chandra 2000: 429).

Nas representações mais antigas que chegaram aos dias atuais, ele aparece como Padmapāni, em que segura o lótus, como nos exemplares de Gandhāra (Loriyan Tangai e Swat), em pé ou sentado; ou de Mathurā, em pé, dos séculos I-III d.C. (Fig. 7). Uma passagem do diário de viagem do monge Fa-Hsien menciona a adoração de Avalokiteśvara em Mathurā, entre 399-413 d.C. Por vezes,
Avalokiteśvara é identificado com um bodhisattva que aparece segurando um frasco (kalaśa ou kuṇdika) contendo néctar ( $a m r t a)$; entretanto, nesse caso, a atribuição depende de inscrições que corroborem a identificação, pois ela se confunde com a representação de Maitreya. A representação de Padmapāṇi tem continuidade no período Gupta, como, por exemplo, em $\mathrm{Na}$ landa, desde o século IV até o IX d.C. Essa forma do Bodhisattva aparece também em relevos nas grutas de Maharashtra e do Gujarat (Fig. 8), e tornou-se recorrente a partir do século $\mathrm{V}$ d.C. Uma pintura mural de Avalokiteśvara, presente na Gruta 1 de Ajanta, é uma de suas representações mais célebres (Fig. 9). Nesse sentido, Padmapāṇi provavelmente seja a representação de Avalokiteśvara cujas referências iconográficas mais remotas tenham sobrevivido.

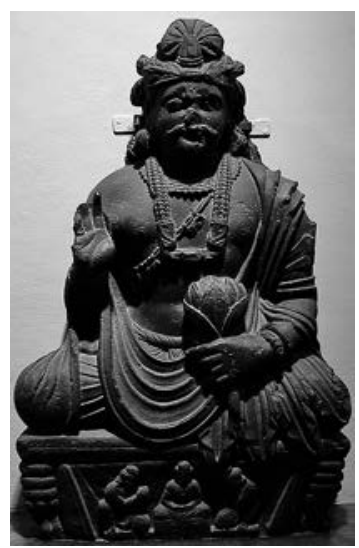

Fig. 7. Escultura de Padmapāṇi, Vale do Swat, Gandhāra, século I-III d.C., xisto. Indian Museum, Calcutá, Índia (Fonte: Aldrovandi 2002).

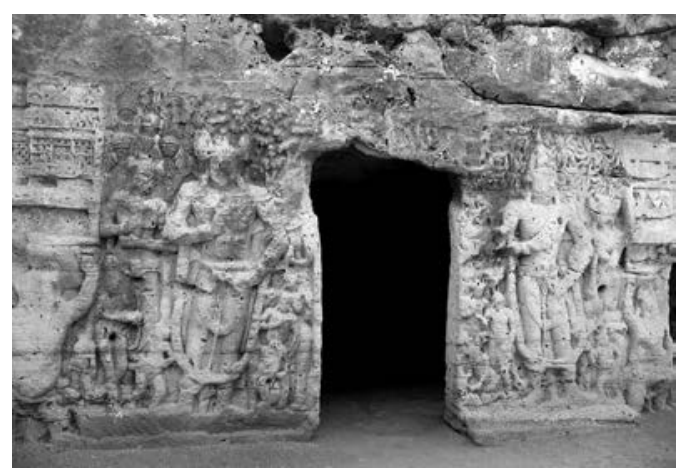

Fig. 8. Relevo com Padmapāṇi e Vajrapāṇi entre devotos na fachada externa do caityagrha das grutas Khambalida, Gujarat, Índia, in situ, c. século III-IV d.C. (Fonte: Aldrovandi 2010). 


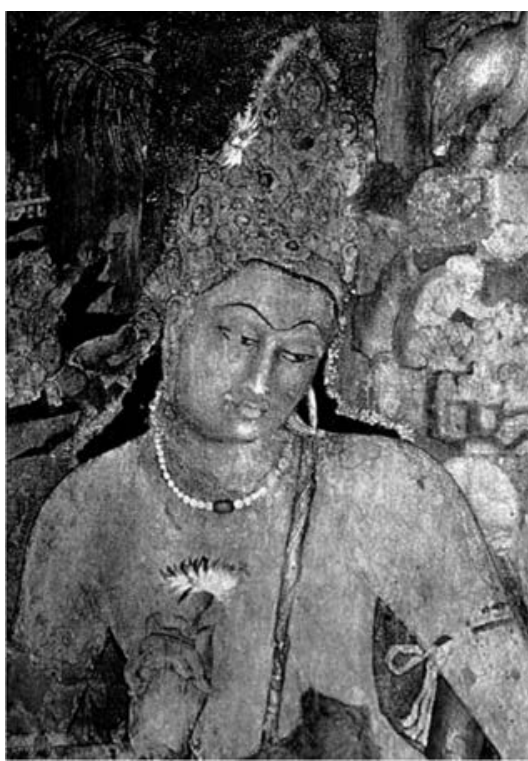

Fig. 9 Pintura mural de Padmapāni, Gruta 1 de Ajanta, século V d.C. Maharashtra, Índia, in situ (Fonte: Aldrovandi 2004).

Além do $K V$, existem outras fontes textuais mais tardias sobre Avalokiteśvara, como o Lokeśvaraśataka, do século IX d.C.; o Mañjuśrimūlakalpa, dos séculos VIII-X d.C.; e o Sādhanamālā, do século XII (v. Tucci 1948; Mallmann 1967; Chandra 2000).

A forma Lokanātha é descrita como de cor branca, "resplandecente como a lua", com um lótus vermelho na mão esquerda e o varadamudrā na direita. Em outros casos, o caule do lótus é longo e sobe pelo lado esquerdo de seu corpo, até a altura da cabeça. Fontes textuais e iconográficas mais tardias também mencionam o vitarkamudrā, também descrito como sūcimudrā. Ele usa o jațāmukuța (coroa de cabelo trançado) e pode ter uma imagem de Amitābha (Amitāyus) em meditação, na coroa. Um raro exemplar de bronze de Gandhāra, do século III, apresenta esse atributo (Fig. 10). Na iconografia, ele aparece adornado de joias, em pé ou sentado em lalitāsana ou vajrāsana.

No manuscrito do Asțasahasrikā, de 1015 d.C. (Cambridge, Add. 1643), há uma série de miniaturas do Bodhisattva sentado e em pé, acompanhado por várias divindades. Nele, o Lokanātha de Svayambhū aparece representado

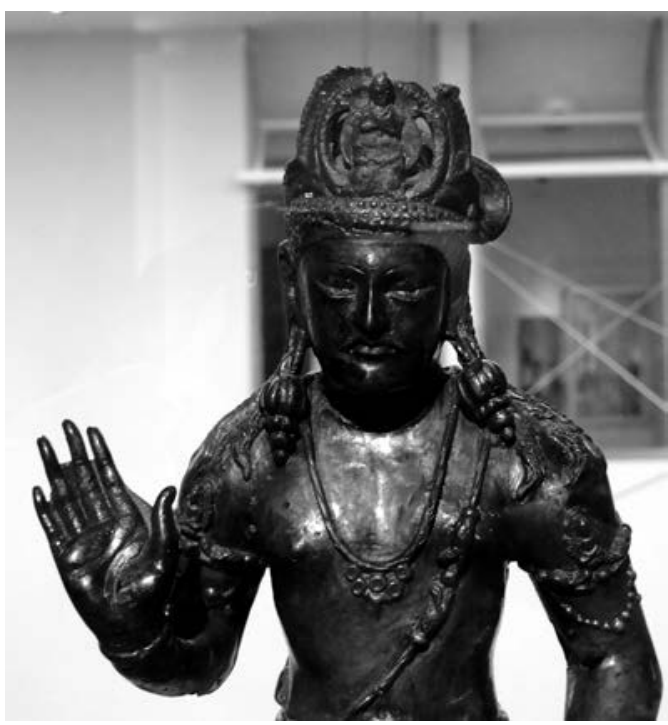

Fig. 10. Escultura de Avalokiteśvara com o Buda Amitābha na coroa, bronze (com alta percentagem de estanho). Gandhāra, século III d.C. Musée Guimet, Paris (Fonte: Aldrovandi 2011).

em pé, com varadamudrā e um lótus e um frasco. Em outro exemplar desse manuscrito, um Lokanātha aparece sentado em vajraparyañka, com varadamudrā e dois lótus vermelhos passam pelos braços, ladeado por duas deusas, uma amarela, outra vermelha. Ainda nesse manuscrito há miniaturas em que Avalokiteśvara aparece em dhyānamudrā e em dharmacakramudrā. (v. Chandra 2000: 431, 436, 440, 449). $\mathrm{Na}$ iconografia, uma postura sentada, que depois se tornou recorrente, é o ardhaparyañka, com um pé pendente repousando sobre um lótus. A postura em pé pode ser o samapada ou o tribhañga, com três flexões ou ângulos, como aquela encontrada na Gruta 1 de Ajanta. A imagem mais antiga de Lokanātha no Nepal está no Dhvaka Baha em Katmandu, datada de cerca do século VII d.C. Há também um bronze do século XV, sem Amitābha na coroa (v. Kramrisch 1964: 29, pl. V; 134, pl. 30). Ele também aparece entre os 108 Lokeśvaras no Macchandar Bahal de Katmandu, como Āryāvalokiteśvara.

O manuscrito nepalês Dharmakośasangraha, redigido por Amṛtānanda no século XV (Bhattacharyya 1958: 3), descreve essa forma de Lokanātha da seguinte maneira: varadalokeśvara 
ekamukha dvibhuja varadam padmahastam

["Varada Lokeśvara: uma cabeça, dois braços, uma mão em varadamudrā, o gesto de doação, e uma com um lótus"]; mas também aparece como Abhaya Lokeśvara, com abhayamudrā e um lótus. Em outros dois excertos dessa fonte o nome utilizado é Padmapāṇi [padmapāṇi ekāsya dvibhuja varadakamaladharah; dakse padmapānisañghah varadamudrā padmadhārī] (fl. 60; apud Chandra 2000: 431, 444). Ainda nesse manuscrito é dito que Padmapāṇi pertence à família do lótus, seu Buda é Amitābha, sua consorte, ou prajña é Bhṛkuțī Tārā, e Sukhāvatī, seu paraíso; é dito ainda que Amitābha criou Padmapāṇi em virtude do conhecimento equânime (samatājñāna). Essa fonte fornece uma longa explicação sobre como Padmapāṇi emanou da meditação de Amitābha e ficou conhecido como um dhyānibodhisattva, com a mão direita ele outorgou uma benção e com a esquerda ele ofereceu aos mundos as pétalas do lótus, do qual ele recebeu seu nome. A explicação do nome Avalokiteśvara, nesse texto nepalês, segue o KV. Uma explicação fornecida por Chandra (2000: 432, 461) menciona que o botão de lótus representa as mentes dos seres, que, originalmente são puras, mas estão recobertas pelos desejos e a ignorância; o Buda, em sua coroa, significa que Avalokiteśvara pertence ao Paraíso do Oeste, presidido por Amitābha. $\mathrm{O}$ autor acrescenta que o lótus aberto representa a mente iluminada dos Budas.

No Asțasahasrikā [1643, fol. 184] e no Dharmakośasanigraha [59] há representações com quatro (Caturbhuja Lokeśvara) e seis braços (Saḍbhuja Lokeśvara), com espada, flecha, varada, lótus, livro, arco; também pode aparecer com um frasco, uma tridandịi, ou o laço de Amoghapāśa (v. Chandra 2000: 457 58). O número de braços cresce, podendo ter $8,10,12,16,18$, até mil braços (Sahasrabhuja Avalokiteśvara), e o número de atributos ou das mudrā também varia (v. Chandra 2000: 464-65).

Oito bodhisattvas são descritos nas pétalas de lótus de seu mandala, no centro do qual ele aparece entre Hayagrīva e Tārā. São eles: Maitreya, Kșitigarbha, Vajrapāni, Khagarbha, Mañjughoșa, Gaganagañja, Viṣkambhin,
Samantabhadra, cercados por quatro deusas Dhūpā e com os portais guardados por quatro deusas (v. Mallmann 1975: 107; Wayman 1992: 83, 88-9, 104). O Vairocanābhisambodhitantra (VAT) [O Tantra da iluminação manifesta de Vairocana], foi datado do século VI d.C., por Wayman (1992: 8), a partir das descrições iconográficas presentes em seu capítulo 2 e, segundo o estudioso, teria sido composto em Maharashtra. Uma descrição detalhada presente no VAT [8088; 117-18] descreve o mañ dala de Amitābha (Wayman 1992: 123). Nele, Avalokiteśvara é descrito "sentado num lótus branco, qual uma concha e a lua de outono, sua face sorrindo suavemente, com Amitābha sentado em sua cabeça”. À sua direita está a deusa Tārāa, de cor verde, as mãos unidas segurando a flor utpala (lótus azul) e vestindo roupas brancas. À direita está a deusa Bhṛkuțī com um rosário e três olhos, de cor branca (associada aos ritos apaziguadores, śāntika). Ao lado dela está Mahāsthāmaprāpta, que carrega um lótus em botão e tem vestes brancas. Ao lado dele, a Vidyādevī Yaśodharā, dourada e com ornamentos (ritos de prosperidade, pauștika, semelhante a Vasudhārāa). Ao lado de Tārā está Pāṇdaravāsinī, de cor vermelha, com vestes brancas, segurando um lótus (ritos de dominação, vaśíkara). Depois dela (ou abaixo dela) está o Vidyārāja Mahābala, da cor do sol nascente, adornado com um lótus branco; e Hayagrīva, seu cabelo qual guirlanda flamejante. No lado sul, o senhor Yama segura uma clava na mão e monta o búfalo, da cor de uma nuvem de chuva de verão, cercado das 'mães' [mātṛkā], Kālarātrī-s e Mṛtyu-s. No canto sudoeste, Nirrti (a Destruição), terrível e com o sabre na mão.

A forma Khasarpaṇa de Avalokiteśvara, de acordo com Wayman (1992: 99) seria a mais próxima da descrição no VAT em termos de grupo, quando o Bodhisattva aparece acompanhado de quatro divindades: Tārā (verde), Sudhanakumāra, Bhṛkuțī (com três olhos) e Hayagrīva. O significado de Khasarpaṇa seria "aquele que se move (suavemente) pelo céu". O Buda Amitābha está em sua coroa, como na descrição do VAT. Sua cor, descrita como "pura como a lua", é semelhante ao VAT , "como concha e a lua de outono". 
A monumentalidade discursiva no budismo indo-nepalês: uma estratigrafia das fontes escritas e iconográficas presentes no Guṇakāraṇ̣̂yūhasūtra

R. Museu Arq. Etn., São Paulo, n. 22, p. 3-30, 2012.

Embora existam epítetos comuns nos excertos contendo o Louvor (mahātmya) de Yama a Avalokiteśvara de ambas as fontes - KV e $G K V$-, alguns dos mais significativos, do ponto de vista iconográfico, parecem ter sido alterados ou mesmo suprimidos. Entre eles, o que mais chama a atenção é o epíteto ekādaśaśírșa ou ekādaśamukha, que descreve a forma de Avalokiteśvara com onze cabeças. Enquanto ekādaśaśîrșa está presente no Louvor de Yama do $K V$, não existe qualquer menção a essa forma de Avalokiteśvara na mesma porção do Louvor apresentado no Capítulo 2 do GKV. Na verdade, esse epíteto aparece uma única vez em todo o GKV, como ekādaśaśiras, no Capítulo 17 [v. 417].

A forma Ekādaśaśīișa ou Ekādaśamukha, por sua vez, remete a uma rara representação iconográfica desse Bodhisattva encontrada na Gruta 41 do monastério indiano de Kanheri na costa oeste da Índia, datada do final do século V d.C. (Fig. 11). Essa figuração incomum é um indício claro de que práticas esotéricas budistas avançadas ocorriam nesse monastério, no mínimo, desde aquela época. Na Índia, imagens desse tipo são bastante tardias e foram encontradas na Caxemira e na região leste (Orissa e Bengala). Essa representação se tornou frequente na iconografia mais tardia, especialmente no Nepal, no Tibete, na China e no Japão. A presença dessa representação em Kanheri atesta sua origem indiana. De acordo com as fontes literárias e iconográficas, as onze cabeças estariam associadas, segundo Huntington (1985: 265), à representação dos daśabhūmika - os dez estágios de realização do bodhisattva -, encimadas por uma cabeça de Buda (a décima primeira), representando a realização final.

A forma Simhhanāda Lokeśvara é descrita como o $85^{\circ}$ dos 108 Lokeśvaras nepaleses, presente no Macchandar Bahal, montado em um leão. Uma imagem de Avalokiteśvara proveniente de Mathurā apresenta uma cabeça de leão entre as pernas. Como observou Huntington (1985: 197) essa é uma referência clara da forma Simhhanāda de Avalokiteśvara, traduzida para o estilo do idioma escultural de Mathurā.

A forma Āryāvalokiteśvara, descrita como o 108 dos Lokeśvara nepaleses aparece no Mac-

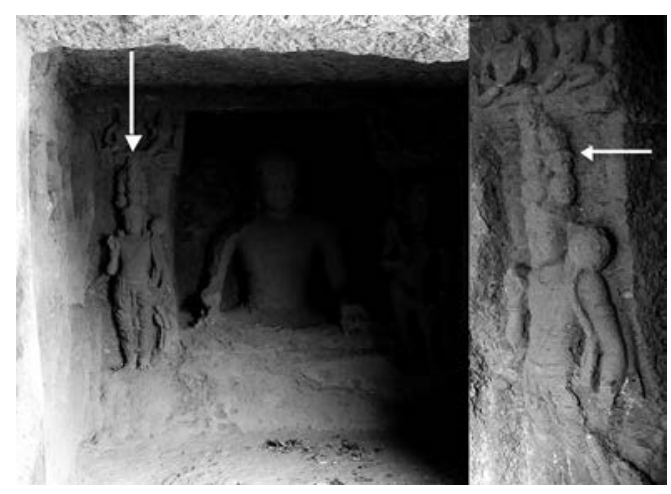

Fig. 11. Relevo com Buda entre os Bodhissatvas Padmapāṇi e Vajrapāṇi. Detalhe lateral da figura de Padmapāṇi Avalokiteśvara com onze cabeças. Gruta 41 de Kanheri, Maharashtra, Índia, in situ. Final do século V d.C. (Fonte: Aldrovandi 2005).

chandar Bahal segurando um vajra e um lótus (v. Bhattacharyya 1958: 432; Chandra 1984: 341).

O Kārandavyūha Lokeśvara é descrito como o $37^{\circ}$ Lokeśvara nepalês com o vajra e um livro (v. Bhattacharyya 1958: 398; Chandra 1984: 358).

A forma Sadākșari, associada ao mantra e muito recorrente na iconografia, é descrita sentada com quatro braços, dois em añjalimudrā, uma mão segura um rosário $(m \bar{a} \bar{a})$ e a outra um lótus. Em Nalanda e Orissa encontra-se uma forma em pé de Avalokiteśvara com quatro braços, uma mão em varadamudrā, as demais seguram um frasco, um rosário e o lótus. $\mathrm{O}$ protótipo é atribuído ao período Gupta, uma imagem com os mesmo atributos se encontra na gruta 26 de Ajanta.

Amoghapāśa Avalokiteśvara, aquele que carrega o infalível (amogha) laço (pāśa), que simboliza a habilidade do Bodhisattva de salvar todos os seres sencientes, sem exceção, resgatando-os do saṃsāra. A corda também simboliza o seu voto ou as quatro virtudes, capazes de levar os seres à iluminação. As fontes também mencionam uma rede, que ele utiliza para resgatar os seres dos diferentes reinos. $\mathrm{O}$ Amoghapāśahṛdayasūtra descreve o seu culto. Este sūtra, de acordo com Chandra (1999: 291), possui uma estrutura semelhante ao Mahāvairocanāsūtra. Registros mencionam que o primeiro capítulo dessa fonte foi traduzido 
para o chinês em 587 d.C. em Gandhāra, por Jñanagupta. Há registros de outras traduções dessa fonte até o século XI d.C., inclusive uma de Hsuan-tsang, de 659 d.C. A descrição de Amoghapāśa nos cânones tibetanos aparece com uma cabeça e oito braços, branco como a lua de outono, sentado ou em pé em samapada. Sua iconografia aparece associada à imagem de Amitābha na coroa, uma pele de cervo no ombro esquerdo e de tigre no colo; nas mãos, além do laço, os atributos incluem o varadamudrā, um frasco, ou joia, ou bastão triplo (tridanda) e o lótus. Nos casos em que possui seis ou oito braços, duas mãos costumam estar em añjalimudrāa, mas as representações podem ter 12 ou 22 braços. Essa representação tornou-se recorrente na Indonésia e no Nepal. Chandra (1999: 307) fornece uma lista de imagens nepalesas do século XIII ao XIX, muitas com inscrições com a datação precisa.

No seu mandala, Amoghapāśa aparece cercado por 15 divindades. No mandala Garbhadhātu, aparece como o quarto Bodhisattva do quadrante de Avalokiteśvara. O culto nepalês a Amoghapāśa e os rituais realizados com seu mandala são descritos em grande detalhe por Locke (1987). O Amoghapāśa branco é uma das divindades mais populares do Nepal, é uma das oito divindades tutelares do Vale do Katmandu. Sua adoração é chamada aștamivrata, um ritual fundamental do budismo newār, descrito no aștamīvratamāhātmya, que consiste de contos (avadāna) populares que ilustram os méritos alcançados por meio desse voto realizado no oitavo dia (quinzena da lua cheia), todos os meses. O Amoghapāśa vermelho está associado às chuvas e os rituais dedicados a ele contam com a presença do rei.

Outro epíteto a atrair a atenção, também presente no Louvor de Yama do Capítulo 2 do GKV [v. 293], é śatasahasrahasta, que descreve uma forma de Avalokiteśvara com cem mil braços e que, no $K V$, por sua vez, aparece como śatasahasrabhuja. No entanto, essa forma de Avalokiteśvara é geralmente descrita nas fontes como sahasrabhuja-sahasranetra, ou seja, "[com] mil braços [e com] mil olhos”, a forma cósmica do Bodhisattva que, na iconografia, aparece com os olhos nas palmas das mil mãos. A multiplicação exponencial do número de braços e olhos, de mil para cem mil, parece configurar um indício de monumentalização discursiva específica dessas fontes que reverberou no fecundo repertório iconográfico a elas associado.

\section{A estratigrafia do Guṇakāraṇḍavyūhasūtra: prototexto, intertexto e metatexto}

Durante o primeiro ano de estudo do Gunakāraṇdavyūhasūtra foi elaborada uma análise das três camadas da estratigrafia literária que compõe essa fonte textual. A primeira camada, que chamamos o prototexto, é o Kārandavyūhasūtra, o texto original indiano com o qual o GKV foi confundido de modo recorrente. Em seguida, a segunda camada ou intertexto é o próprio Gunakārandavyūhasūtra, o texto em si mesmo e toda a interdiscursividade que o compõe, capaz de criar uma monumentalização narrativa por meio das estratégias discursivas que os sacerdotes budistas nepaleses empreenderam com base no prototexto. Uma terceira camada também começou a ser vislumbrada durante a análise e foi denominada metatexto.

\section{Kārandavyūhasūtra: o prototexto}

A principal fonte do GKV, da qual deriva inclusive seu nome, é o Kāraṇdavyūhasūtra $[K V]$, um tratado Mahāyāna do século IV-V d.C., cuja narrativa compreende um diálogo entre o Buda Śākyamuni e seu interlocutor, o Bodhisattva Sarvanīvaranavișambhin, no parque Jetavana, próximo à cidade de Śrāvastī. O texto descreve as histórias milagrosas e os atos compassivos do Bodhisattva Avalokiteśvara, que resgata os seres sencientes do sofrimento em diferentes mundos (v. Locke 1980, 1985; Tuladhar-Douglas 1989, 2006; Lienhard 1993), e apresenta e explica a șadakșari mahāvidy $\bar{a}-\mathrm{o}$ grande conhecimento de seis sílabas -, o mantra budista Om mani padme hūm (Studholme 2002: 61). Embora Studholme (2002) tenha proposto uma influência Śaiva para o surgimento desse mantra, em um meio purânico, a ausência de 
A monumentalidade discursiva no budismo indo-nepalês: uma estratigrafia das fontes escritas e iconográficas presentes no Guṇakāraṇdavyūhasūtra

R. Museu Arq. Etn., São Paulo, n. 22, p. 3-30, 2012.

uma edição crítica dessa fonte textual mantém essa hipótese sem fundamentação apropriada.

Os manuscritos mais antigos preservados do KV são provenientes de Gilgit, elaborados por volta de 630 d.C., descobertos pelos professores Raghu Vira e Lokesh Chandra e atualmente preservados nos Arquivos Nacionais, em Nova Delhi. Com base nas divergências textuais das duas cópias mais antigas existentes, Mette $(1993,1997)$ sugeriu que o texto é uma composição originária dos séculos IV ou V d.C., o que o insere entre os sūtra relativamente tardios Mahāyāna, como o Lañkāvatāra e o Vimalakirtinirdeśa. Existe uma transliteração do texto publicada por Vaidya (1961). Durante nosso estágio de pesquisa no EFEO em 2011, tivemos acesso a uma edição do texto original publicada por Samasrami (1873).

A época de composição do GKV é pelo menos um milênio mais tardia. A estratégia empreendida por seus realizadores foi alegar que o GKV era, de alguma maneira, idêntico ao $K V$, ou um aprimoramento dele. No colofão de ambos, essas obras são conhecidas pelo mesmo nome, como os Āryāvalokiteśvaragunakāraṇdavy ūha-mahāyānasūtrarāja ["O rei dos compêndios Mahāyāna do sūtra da explicação do conjunto das qualidades do nobre Avalokiteśvara”].

Ocorre que, por razões que serão discutidas mais à frente, essas duas obras, GKV e $\mathrm{KV}$, foram recorrentemente confundidas pelos estudiosos, o que durante décadas dificultou seu estudo e análise. O GKV é uma versão expandida do KV, em forma métrica. Ambos são descritos como um "conjunto de caixas", devido ao fato de a forma literária apresentar histórias contidas umas dentro das outras, como narrativas complexas e emolduradas (framing narratives) de modo concêntrico.

Além do nome, o GKV emprestou de seu texto-base, ou prototexto, tanto o tema principal como a sequência narrativa. Ao se estabelecer como uma extensão do $K V$, o texto mais antigo o autoriza (v. Tuladhar-Douglas 1989). Essa validação possibilitou a sobreposição de camadas narrativas e outros materiais mais recentes e diretamente associados às necessidades de uma comunidade budista mais tardia. Isso se insere nas questões discutidas por Katz (1982: xviii) da forma como uma tradição religiosa baseada em uma tradição mais antiga - Vajrāyana e Mahāyāna, no caso -, embora afirme ter sua própria identidade conceitual e mítica, lida com as tensões dessa continuidade e dessa divergência. Ao fundamentar a escritura tardia no texto mais antigo, de tradição indiano-budista, a continuidade da tradição medieval nepalesa é legitimada e, ao mesmo tempo, a vitalidade da antiga tradição é garantida e estendida por mais de um milênio.

No milieu indiano antigo, o ato de copiar uma tradição textual era considerado a asseveração de pertencimento a uma tradição mais antiga e reputada. O paradigma do conhecimento consistia na própria repetição da fonte primária seguida dos respectivos comentários. Dessa forma, os textos antigos acumulavam novas camadas de explanações e paráfrases que dependiam do texto original para sua autoridade e hierarquia.

Esse mesmo mecanismo foi utilizado na confecção do GKV no período Medieval nepalês. Por isso, essas narrativas entretecidas - presentes no GKV e no KV - são aqui consideradas como um tipo muito peculiar de palimpsesto, repositórios de intertextualidade e simulacros da realidade social das antigas sociedades em que esses textos foram criados.

O KV e o GKV são compostos por uma narrativa concêntrica em homenagem a Avalokiteśvara. Em termos formais, ela apresenta uma sucessão de diálogos que emolduram o fio condutor da narrativa, costurado pela atribuição ao Bodhisattva de uma série de epítetos e pela descrição da forma correta de devoção a ele e, ainda, pela enunciação de fórmulas que descrevem o caminho pelo qual Avalokiteśvara resgata os seres do samsāra - o ciclo de reencarnações. Entretanto, essas camadas narrativas múltiplas nem sempre aparecem claramente evidenciadas ou estão facilmente discerníveis à primeira leitura.

A figura do Bodhisattva Avalokiteśvara, por sua vez, foi muitas vezes associada ideologicamente aos reis budistas, na Índia e no Nepal medievais, que adotavam seu epíteto, Lokeśvara 
(o "Senhor do Mundo"), e procuravam assimilar e difundir seu ideal de compaixão por todos os seres sencientes. Exemplos de imagens dos reis produzidas à semelhança do Bodhisattva são mencionadas na literatura e são recorrentes também no Sudeste asiático, como por exemplo no Camboja (v. Chandra 2000: 432).

\section{Guṇakāraṇḍavyūhasūtra: o intertexto}

As histórias presentes no

Gunakārandavyūhasūtra fazem parte, originalmente, de outro texto, mais antigo, o Kāraṇdavyūhasūtra, que serviu de modelo para a maior parte do GKV. De fato, os dois textos foram, frequente e deliberadamente, confundidos ao longo do tempo (v. Burnouf 2010: 24142). Esse intercâmbio intencional de identidades textuais entre os dois textos foi, por sua vez, favorecido pelo milieu em que os textos foram produzidos e é algo que se estendeu ao domínio acadêmico recente.

O GKV, cabe ressaltar, ainda não possui nenhuma tradução ou edição crítica em língua ocidental. A tradução em inglês de Chen (2006), por exemplo, além de pouco rigorosa, embora seja intitulada Avalokiteśv aragunakārandavyūhasūtra é, na realidade, uma versão do Kāraṇ̦avyūhasūtra e não do Gunakāraṇdavyūhasūtra e, mais uma vez, reitera a confusão entre essas obras. Nesse sentido, o próprio KV também ainda não possui uma edição crítica em inglês, embora figure entre os mais importantes sūtra Mahāyāna e costume ser considerado e identificado como o mais antigo tantra budista de Avalokiteśvara (cf. T.-Douglas 2006: 2). Como vimos, a evidência mais remota do $K V$ aparece no material de Gilgit, que vem sendo estudado e editado sistematicamente por Mette (1993; 1997), em alemão.

Como mencionado anteriormente, a segunda porção do KV é possivelmente a fonte original do mais célebre mantra budista, o șadaksarī mahāvidyā. Mas o poder e ubiquidade do șadakșarī mahāvidyā não podem ser subestimados, nem a influência do $K V$ no desenvolvimento do budismo indiano e himalaico. Do ponto de vista literário, portanto, não é de surpreender que um mestre budista nepalês do século XV escolhesse esse exato texto como a base sobre a qual criar um novo sūtra para seu próprio povo e tempo. $\mathrm{O}$ fato de o GKV ser uma produção nepalesa ainda não é amplamente conhecido e Tuladhar-Douglas (1989) considera que o mantra e o sādhanā do Bodhisattva, ali contidos, o estabelecem como um texto Vajrāyana, comparável aos Kriya Tantra. Para o estudioso não há dúvida que o GKV emprestou do $K V$ sua estrutura e seu material narrativo mas, apesar disso, não importa o quanto o GKV deva ao KV como fonte, ele é inquestionavelmente um texto newār. $\mathrm{O}$ conteúdo mítico e ritual do GKV, bem como sua linguagem e estilo distintivos, o localizam no contexto medieval nepalês, junto de outras obras sânscritas budistas nepalesas que formam o que esse estudioso chama de Literatura Guirlanda (T.-Douglas 2006: 2, 12).

O GKV também se apoia em outras fontes dentro da literatura budista sânscrita, em especial no Bodhicaryāvatāra [BCA] (v. Tucci 1923; T.-Douglas 2006: 57-61; Sharma 1990; Crosby e Skilton 2008); além disso, ele descreve e recomenda uma série de votos e rituais que são tipicamente newār, embora suas raízes remontem à tradição budista indiana. A determinação das fontes originais do texto, sua datação e as razões para sua composição, assim como a investigação histórica do seu principal culto - o de Amoghapāśa Lokeśvara, como vimos, uma manifestação de Avalokiteśvara e uma das divindades mais populares do Nepal, sendo uma das oito divindades tutelares do Vale do Katmandu -, permitem refletir sobre o lugar social e político dessa obra textual, desse culto e de Avalokiteśvara, de modo geral. Para os budistas newāri, é a divindade principal do GKV que o distingue do $K V$ e estabelece seu pertencimento cultural: Karunāmaya, o grande Avalokiteśvara nepalês, o último Amoghapāśa que sobreviveu e o guardião do bem-estar de todos os budistas nepaleses (v. Locke 1980, 1987).

Nesse sentido, as relações de intertextualidade e intericonicidade (v. Kristeva 1967; Fiorin 2003; Aldrovandi 2009) presentes nessas duas fontes, $K V$ e GKV, favorecem uma análise sob o ponto de vista de uma monumentalização 
A monumentalidade discursiva no budismo indo-nepalês: uma estratigrafia das fontes escritas e iconográficas presentes no Guṇakāraṇdavyūhasūtra

R. Museu Arq. Etn., São Paulo, n. 22, p. 3-30, 2012.

narrativa, observada nas estratégias discursivas budistas nepalesas, a partir do século XV d.C., principalmente, mas que remontam à Índia dos séculos IV-V d.C. Indícios dessas ações vestigiais transparecem possivelmente na própria interdiscursividade (v. Foucault 1969: 35-36, 178) a que o budismo esteve sujeito ao longo dos vários séculos de sua transmissão. Em Arqueologia do saber, o pensador assevera que:

$\mathrm{O}$ que pertence propriamente a uma formação discursiva e o que permite delimitar o grupo de conceitos, embora discordantes, que lhe são específicos, é a maneira pela qual esses diferentes elementos estão relacionados uns aos outros: a maneira, por exemplo, pela qual a disposição das descrições ou das narrações está ligada às técnicas de reescrita; a maneira pela qual o campo de memória está ligado às formas de hierarquia e de subordinação que regem os enunciados de um texto; a maneira pela qual estão ligados os modos de aproximação e de desenvolvimento dos enunciados e os modos de crítica, de comentários, de interpretação de enunciados já formulados etc. É esse feixe de relações que constitui um sistema de formação conceitual (Foucault 1969: 65-66).

As principais diferenças entre as duas obras - GKV e KV - foram enumeradas por T.-Douglas (2006: 3) e são apresentadas a seguir resumidamente. A primeira delas, como mencionamos, é que o GKV envolve toda a narrativa do $K V$ em duas outras molduras concêntricas. A mais externa delas estabelece um diálogo entre o rei Jinaśrī e o mestre Jayaśrī e já havia sido observada por outros comentadores como um elemento comum em outros textos compostos na mesma época (Brinkhaus 1993; Tatelman 1996). A segunda moldura apresenta um diálogo entre o imperador Aśoka e o mestre Upagupta. Na verdade, esse elemento já havia sido comentado, mesmo sem ter sido totalmente compreendido em 1844 por Burnouf (2010), mas apenas recentemente sua importância como um elemento diagnóstico foi reconhecida
(T.-Douglas 2006). Outro elemento distintivo é que o GKV é todo composto em verso. $\mathrm{O}$ terceiro elemento diz respeito ao tamanho dos sūtra, o GKV é quase duas vezes mais longo que o KV. Finalmente, o GKV é um texto tardio Vajrāyana, como fica demonstrado pelo uso de iconografia e elementos rituais mais recentes, bem como pelo seu foco no culto de uma forma especificamente nepalesa de Avalokiteśvara Karunāmaya. Como observou o estudioso, "se por um lado o $K V$ fornece o esqueleto do GKV, o $B C A$ guarnece seu interior. (...) $O$ uso de versos do BCA no GKV é bem conhecido entre os estudiosos budistas newār" (T.-Douglas 2006: 4).

A monumentalização, em termos formais e físicos, é observada claramente na iconografia e na arquitetura budistas desde os primeiros séculos a.C., por meio do aumento sensível das dimensões das imagens, das proporções e do hibridismo dos edifícios monásticos, bem como na grandiloquência da paisagem que os cerca. Ela aparece refletida na ampliação da visibilidade, materializando e legitimando o discurso budista, em um milieu cada vez mais hierarquizado, com vistas ao fortalecimento da sua identidade (v. Aldrovandi 2006, 2008). Na iconografia, ela pode ser equiparada, em certos momentos, à chamada "Virada Icônica", ou pictórica (v. Yiengpruksawan 1999), na qual a imagem se torna o paradigma em detrimento do texto, resultando em uma tendência à saturação dos espaços pictóricos, pela recorrência das imagens e pela intenção de favorecer a literalidade visual dos discípulos. Ao mesmo tempo, um aspecto que ainda não foi explorado em profundidade diz respeito às maneiras de monumentalizar o próprio texto. No budismo indiano, uma delas está relacionada à ampliação - quantitativa e qualitativa - de narrativas milagrosas ou sobrenaturais relacionadas aos poderes dos Budas e Bodhisattvas, as quais foram ao longo do tempo sobrepostas aos excertos originais. Indícios de tais transformações do discurso estão geralmente associados a irregularidades ou disparidades entre as fontes textuais e iconográficas, muitas vezes de caráter sutil, presentes nas narrativas. Como ficou demonstrado, os acréscimos narrativos presentes nas fontes textuais 
do Mahāparinirvāna do Buda coincidem com episódios específicos da iconografia da escola de Gandhāra (séculos I-III a.C.), os quais justamente apresentam, por assim dizer, disparidades formais (v. Aldrovandi 2006: esp. 387-419).

Nesse sentido, a análise do Gunakārandavyūhasūtra vem demonstrando que, no Nepal, a monumentalização textual também se tornou, no século XV d.C., um instrumento importante do próprio discurso narrativo e de legitimação das elites sacerdotais. Dessa maneira, a evidenciação dessa estratigrafia - as camadas narrativas sobrepostas no texto - em termos cronológicos, isto é, sincrônicos e diacrônicos, permite verificar e discernir os elementos mais antigos e os acréscimos posteriores presentes no GKV. Efetuados esses achados, as mudanças às quais o discurso budista foi submetido tornam-se observáveis e, em um momento seguinte, possibilitam uma confrontação com seus paralelos iconográficos para uma comparação analítica dessas duas vertentes do discurso - uma escrita e outra imagética.

A análise de T.-Douglas (2006: 11) estabeleceu que o GKV, assim como outros textos budistas nepaleses, foi composto na metade do século XV d.C., no Nepal - ou Nepal Maṇdala, como também é chamada essa região. Em sua forma original ele tinha cerca de 200 fólios e 19 capítulos. Embora deva ter existido um período de composição em que versões diferentes circularam, há pouca evidência dessa variabilidade e, segundo o pesquisador, parece mais provável que o texto tenha sido composto por uma pessoa ou um pequeno grupo de sacerdotes em um período curto de tempo. Nenhuma mudança substancial foi feita no texto até o final do século XVIII, ou, mais precisamente, o início do século XIX, quando a divisão dos capítulos foi revisada para refletir mais precisamente a sequência presente no $K V$. Isso envolveu a adição de uma pequena quantidade de material textual para que a narrativa se desenvolvesse mais suavemente. Essa revisão é atribuída pelo estudioso a Amṛtānanda, um sacerdote vajrācārya erudito de Lalitpur que pode ter sido parte de um processo de reflexão e edição inspirado pelos interesses do britânico então residente no Ne- pal, Brian Hodgson (cf. T.-Douglas 2006: 33). Algum tempo depois disso, na metade do século XIX, surgiu a primeira tradução nepalesa do texto, preparada a partir da versão tardia com 22 capítulos (v. T.-Douglas 2006: 11).

De acordo com Douglas (2006: 52) existem cerca de 33 manuscritos conhecidos e outros ainda a serem descobertos. As muitas versões diferentes do texto derivam de revisões de períodos pós-Malla. A preparação de um pequeno número de versos editados em sua obra e as respectivas traduções basearam-se em um conjunto de sete manuscritos. Por outro lado, como assevera esse pesquisador, uma edição crítica completa do texto inteiro é um projeto de longa duração, que requer domínio não apenas sobre todos os manuscritos sânscritos existentes, mas também das traduções em newāri, do vasto corpus de rituais associados e do material narrativo.

O manuscrito MAE/USP, nosso objeto de estudo, possui 20 capítulos e seu colofão está datado de 1807, o que o coloca justamente nesse período intermediário da produção do GKV. Entramos em contato com o professor T.-Douglas, que se encontra atualmente no Nepal realizando pesquisas em outra área do conhecimento. A respeito desse manuscrito, ele nos enviou as seguintes informações:

As versões com 20 e 21 capítulos são mais tardias, tipicamente posteriores a 1815 e provavelmente uma invenção de Amṛtānanda. O GKV é um manuscrito muito comum no Nepal e, durante os anos 1970 e 1980, muitos foram vendidos por antigas famílias endividadas. Assim como as tradições de manuscritos da Perfeição da Sabedoria e do Gandavyuha, as ilustrações em cada manuscrito KV ou GKV, por vezes, estabelecem uma espécie de estágio das divindades que fornecem um contexto para a narrativa; algumas vezes ele reflete a narrativa; algumas, simplesmente reflete a preferência iconográfica do patrono ou do artista. Para trabalhar com a iconografia dos manuscritos seria preciso decidir entre a iconografia de um manuscrito específico, nesse caso seria necessário ler o colofão 
A monumentalidade discursiva no budismo indo-nepalês: uma estratigrafia das fontes escritas e iconográficas presentes no Guṇakāraṇdavyūhasūtra

R. Museu Arq. Etn., São Paulo, n. 22, p. 3-30, 2012.

e estabelecer o contexto histórico e geográfico, ou analisar vários manuscritos para comparação. Eu conheço apenas dois manuscritos do GKV nos quais a iconografia transmite a narrativa, todos os demais têm ilustrações divergentes, embora com elementos comuns (T. -Douglas 03/06/2011, informação por mensagem escrita, tradução nossa).

A obscuridade em que esteve envolta a literatura Sânscrita Budista Nepalesa, isto é, os sūtra compostos no Nepal após 1200 d.C., também ofuscou o reconhecimento do gênero mais profuso dessa literatura, os chamados textos Guirlanda. Entre a vasta quantidade de textos budistas em sânscrito preservados no Nepal, há um número significativo de sūtra que foram compostos na própria região. Nas palavras de Douglas (2006: 39), "a pressuposição anterior, que existiu entre os estudiosos do budismo indiano, sempre viu os newār como um repositório essencialmente passivo, uma espécie de museu vivo que convenientemente preservou os textos essenciais de um milênio antes". Embora os estudiosos familiarizados com o budismo do Vale de Katmandu sempre tenham afirmado que havia alguns textos, notadamente o Svayamibhü Purāna $[S v P]$, que eram composições newār, a extensão em que a tradição budista sânscrita herdada por eles foi adaptada, retrabalhada e composta pelos mestres Vajrāyana nepaleses somente foi reconhecida nos últimos anos.

A existência de gêneros distintos e coerentes dentro do corpus de textos sânscritos budistas nepaleses foi comprovada durante os levantamentos dos manuscritos e de suas edições. Entretanto, a crença equivocada de que muitos desses textos eram originalmente indianos impediu e postergou as discussões sobre esses diferentes gêneros literários nepaleses. $\mathrm{O}$ mais proeminente entre eles é um conjunto monumental de compilações de histórias de caráter didático associadas à realização de votos leigos, chamados textos mālā ("Guirlanda"), presentes entre as coleções de literatura avadāna. Para T.-Douglas (2006: 40), esse conjunto denominado avadānamātā é mais amplo que aquele definido apenas pelos textos que possuem essa terminologia em seus próprios títulos (e.g. Aśokāvadānamālā).

Os elementos formais distintivos presentes nos textos medievais sânscritos budistas nepaleses que formam a Guirlanda de Histórias (avadānamālā) foram identificados, elencados e descritos por Douglas (2006: 39-51). Esse conjunto específico de gênero literário medieval, de definição politética, foi composto durante poucas décadas, aparentemente por volta de 1440 d.C. Elas refletem um sentido histórico de identidade nacional e engendram um movimento que assistiu à decadência da tradição clássica sânscrita e o desenvolvimento do newāri clássico. Entre os textos Guirlanda, existem aqueles que são apenas coleções de avadāna retrabalhadas com o propósito de ajudar os votos leigos, e aqueles compostos como exaltações ou louvor a um personagem, um objeto ou um lugar sagrado - os māhātmya (v. T.-Douglas 2006: 41). Nosso objeto de estudo, o GKV, pertence mais especificamente a esse último gênero.

Todas as versões do GKV são māhātmya baseados no culto de Amoghapāśa Lokeśvara, em Bugamati. Assim como o SvP é um māhātmya baseado no culto de Vagīśvarakīrti Mañjuśrī, no Mahācaitya de Svayamibhū, em Katmandu. As versões mais antigas e as tardias do SvP, quando comparadas, fornecem importantes informações para a datação desse gênero literário, revelam um desenvolvimento gradual bem como a aquisição das características dos textos Guirlanda: a adição da moldura narrativa, o uso de métrica e de outros elementos estilísticos.

A classificação do gênero māhātmya é importante para descrever a literatura sânscrita devocional em geral, mas a coerência específica presente nos textos Guirlanda fornece um esquema classificatório e descritivo mais completo para esse período formativo da literatura nepalesa. Poucas obras apresentam todas as características essenciais, mas existe um conjunto estável de elementos recorrentes, ou mesmo recursivos, presentes em todas elas. Alguns desses elementos, presentes no $G K V$, foram apontados originalmente por Tucci (1923: 615), que descreveu a narrativa como uma "litania interminável que repete monotonamente o núcleo central da 
obra”. A obra a que ele se refere é o KV que, naquela época, ainda era confundida com o GKV. Apesar disso, Tucci (1923) apontou as similaridades entre o GKV e o SvP, evidenciou as citações extensas do BCA e especulou sobre as origens das outras porções em versos de alguns de seus capítulos.

Ao determinar que a composição dos textos Guirlanda é constitutiva da reinvenção do budismo nepalês, é possível iniciar a identificação de elementos únicos dessa nova forma de budismo. Entre os traços característicos dos textos Guirlanda, analisados por Douglas (2006: 41-51), um primeiro elemento a se destacar é a, já mencionada, narrativa emoldurada. Como vimos, esse é um elemento presente no GKV. Sua importância foi identificada originalmente por Brinkhaus (1993) nas formas mais tardias do SvP. Em seu comentário sobre o GKV, Burnouf já havia observado que:

Aqui, como nos Purāṇa, a narrativa não se apresenta diretamente ao leitor ou sem preâmbulo; ela chega, pelo contrário, apenas por intermédio de numerosos narradores, que a recebem uns dos outros, e somente após passar por esses intermediários é que se alcança Śākyamuni, o antigo narrador, ou preferivelmente, o sagrado revelador. Esse é o elemento mais importante que distingue o poema da versão em prosa [i.e., o KV] (Burnouf 2010: 240).

Nos textos Guirlanda, a primeira moldura apresenta Jinaśrī, o rei nepalês, e seu rājaguru Jayaśrī. Uma segunda moldura faz referência a seus predecessores: o imperador Aśoka Maurya e seu mestre Upagupta. A cena é, então, transferida para o Kukutțara Vihāra, onde Aśoka veio a ser instruído por Upagupta no mesmo tópico, naquele caso, as Três Joias (v. Burnouf 2010: 235). Na resposta ao pedido de Aśoka, Upagupta usa quase a mesma linguagem: "Assim como fui instruído pelo meu mestre, o yogi Upagupta, assim eu te instruirei”. Assim, o elemento principal é a moldura dupla e concêntrica. Muitas coleções de avadāna possuem uma moldura narrativa com Aśoka e Upagupta, o que parece ter sido a fonte da moldura duplicada nepalesa.

Enquanto o primeiro capítulo do $\mathrm{KV}$, como em muitos sūtra Mahāyāna, estabelece o cenário para o texto, descrevendo o lugar da pregação do Buda e os vários seres ali presentes, no nosso exemplar do GKV, essa porção corresponde ao capítulo 2 e é envolvida por uma primeira moldura narrativa externa que apresenta o diálogo entre o rei nepalês Jinaśrī e seu mestre Jayaśrī. Em seguida, passa a outro diálogo nidificado e semelhante, entre o imperador Aśoka e o mestre Upagupta. Somente depois do término desse diálogo é que se iniciam, na metade do capítulo 2, as descrições das façanhas de Avalokiteśvara (v. T.-Douglas 2006: 12).

Um elemento interessante dessas narrativas é que o mestre de Upagupta não é ninguém menos que o próprio Buda Śakyamuni. Isso refina o sentido de mestre, uma vez que a tradição acerca de Upagupta deixa claro que ele nunca estudou com o próprio Buda Śākyamuni (v. Strong 1992). Assim como existe uma lacuna histórica entre Upagupta e Śākyamuni, uma vez que o Buda teria vivido pelo menos dois séculos antes de Aśoka Maurya, ela não cria uma barreira para que eles sejam descritos como mestre e discípulo. O hiato cronológico é ainda maior entre Upagupta e Jayaśrī - cuja identidade e a data precisa ainda não foram determinadas, mas que não impede a continuidade linear nos textos Guirlanda, identificada por T.-Douglas (2006). É possível pensar que esses elementos, por um lado, evidenciam e enfatizam a linhagem de mestres budistas, remetendo-os ao próprio Buda histórico, algo favorecido pela liberdade narrativa de seus autores, apesar da ruptura cronológica. Mesmo que historicamente questionáveis, esses elementos contextuais serviam sem dúvida para legitimar a composição narrativa desses textos, aproximando-os do fundador da linhagem.

Um segundo elemento distintivo dos textos Guirlanda diz respeito à presença de uma forma revisada de textos indianos mais antigos, geralmente avadāna em versos, cuja forma métrica mais frequentemente utilizada é o anușțubh (v. Burnouf 2010: 239), além de excertos ou versos finais em métricas mais elaboradas. T.-Douglas 
A monumentalidade discursiva no budismo indo-nepalês: uma estratigrafia das fontes escritas e iconográficas presentes no Guṇakāraṇdavyūhasūtra

R. Museu Arq. Etn., São Paulo, n. 22, p. 3-30, 2012.

(2006: 42) menciona que, nesse aspecto, o GKV é o mais convencional entre os avadānamā $\bar{a}$, algo que Burnouf (2010: 240), em seu comentário, havia descrito como uma "composição clássica no estilo poético dos Purāṇa”. Além de uma porção em métrica trișțubh no primeiro capítulo, ele está todo em anușțubh, com exceção de alguns outros poucos excertos. Além disso, os textos Guirlanda são todos edições revisadas ou compilações de obras indianas em prosa, exceto o SVP. Nesse sentido, o GKV deriva, essencialmente, do KV.

Um terceiro elemento comum aos textos Guirlanda é a ênfase nos vrata. Uma importância reiterada é atribuída aos votos religiosos leigos e aos méritos derivados da realização de um dos três votos mais importantes: o Poșadhavrata (um jejum curto dedicado a Karuṇāmaya), o Vasundarāvrata (jejum dedicado à deusa da prosperidade) ou o Lakșaicaityavrata (oferenda de cem mil pequenos caitya) (v. Locke 1987). Nesse sentido, o primeiro capítulo do GKV contém um longo excursus sobre a importância do Poșadhavrata. O SvP contém um capítulo sobre os doze tìrtha do Nepal, que são parte da versão mais longa do Poșadhavrata e de outros votos.

Em seguida, um quarto elemento diagnóstico é a presença de um capítulo dedicado à adoração das Três Joias do Budismo triratnabhājana. O GKV principia com uma porção extensa de reverência às Três Joias triratna: o Buda, o Dharma e o Samgha. Como observou T.-Douglas (2006: 44), há algum tempo, os newār têm uma compreensão específica sobre o Triratna, personificadas no Ādibuda - o Buda primordial, em Prajñāpāramitā e em Avalokiteśvara. Essas três divindades são recorrentes na iconografia do Nepal Mandala (a região nepalesa), e nos textos Guirlanda. A trindade budista é o tema de metade do primeiro capítulo do GKV e, possivelmente, trata-se de uma prática distintivamente newār. A linguagem do GKV é explícita em mapear deliberadamente a compreensão 'mundana' das Três Joias na trindade divinizada.

Um quinto elemento diz respeito à presença de listas estereotípicas com descrições da ordem social. Um sexto elemento é a descrição do caminho, que pode aparecer repetidas vezes e de forma padronizada. Outro elemento é o uso do epíteto Śrīghana para o Buda Śākyamuni e o Ādibuda que, no GKV, é encontrado no capítulo 2, cuja tradução integral bilíngue foi realizada durante esta pesquisa. Existem também elementos estilísticos comuns a todas essas obras. Assim como, os elementos linguísticos típicos do sânscrito híbrido budista nepalês, mencionados anteriormente.

\section{A narrativa do GKV}

O núcleo narrativo do GKV é uma coleção de quinze (ou mais) histórias sobre as intervenções de Avalokiteśvara, o Bodhisattva que personifica a compaixão em prol de todos os seres sencientes. O Bodhisattva viaja pelos diferentes domínios da cosmologia budista [v. Abhidharmakośabhāșyam], que inclui os infernos, as regiões das almas penadas (preta), dos asura e, também, Jambudvīpa, o mundo terrestre, onde percorre a região de Magadha e os esgotos de Vārāṇasī, sempre com o intuito de resgatar as criaturas desesperadas que encontra em seu caminho. Ele surge de formas variadas e oferece salvação e inspiração aos diferentes seres, que passam a trilhar o caminho budista. A partir daí, todos irão um dia renascer no paraíso celestial de Sukhāvatī e, eventualmente, alcançarão a Iluminação.

Essas histórias encontram-se encaixadas umas nas outras e, ao mesmo tempo, são envolvidas por molduras narrativas concêntricas. Cada história no GKV é narrada em um contexto de ensinamento formal budista, isto é, com um Buda descrevendo os feitos de Avalokiteśvara para uma grande audiência que inclui, por exemplo, o Bodhisattva Maitreya. No início, é o Buda histórico, Śākyamuni, usualmente chamado Śrīghana ["Nuvem de Glória”] que está pregando e seu interlocutor é o Bodhisattva Sarvanīvaraṇaviṣkambhin ["Aquele que elimina todas as obscuridades"]. O que é narrado, no entanto, frequentemente é algo que o Buda Śākyamuni soube quando, ele mesmo, estava sentado diante de um outro Buda anterior (cf. T.-Douglas 2006: 1, 11), o que remete novamente ao que chamamos narrativa cosmológica. 
Essa narrativa principia com o Bodhisattva Sarvanīvaranavișkambhin perguntando pela primeira vez ao Buda sobre Avalokiteśvara depois que ocorre um evento milagroso com luzes radiantes que indicam suas atividades no inferno de Avīci. Cada capítulo seguinte principia com Sarvanīvaranavișkambhin perguntando a Śrīghana quando Avalokiteśvara vai chegar ao jardim em que eles estão conversando. Ele vai fazer isso sucessivamente, em todos os capítulos, até o 16, que marca a divisão entre o primeiro e segundo nirvyūha do KV. Em todas as vezes, o Buda lhe diz que Avalokiteśvara está naquele momento resgatando algum tipo de ser afligido.

As histórias sucessivas, por sua vez, contêm outras molduras narrativas e nesses episódios outros discípulos de eras anteriores também passam a desejar ardentemente conhecer o Bodhisattva Avalokiteśvara, o que faz aumentar ainda mais o desejo de Sarvanīvaraṇaviṣkambhin. Finalmente, no cerne da narrativa, esse Bodhisattva compreende que Avalokiteśvara contém, na verdade, todos os reinos imagináveis em si mesmo. Ele tem uma visão extraordinária, na qual é conduzido em uma viagem pelos poros da pele de Avalokiteśvara. Cada um dos poros contém um reino vasto e habitado por diferentes seres, todos progredindo ativamente no caminho budista (buddhamarga). Dessa maneira, o Buda Śrïghana demonstra para o Bodhisattva que todos habitamos o corpo de Avalokiteśvara e que, portanto, sua chegada é incerta. Como observou acertadamente T.-Douglas (2006: 33), esse texto pertence a um gênero de sūtra Mahāyāna que utiliza visualizações do corpo do Buda como uma imagem da totalidade - como o Avatamsaka -, e está diretamente associado ao empréstimo do mitema do mahāpurușa do hino do Rgveda, o Purușasūkta [X.10.90], que tem paralelos também na cosmologia jainista. No caso do GKV (e do KV), entretanto é o corpo de Avalokiteśvara que contém todos os mundos. O caráter eminentemente soteriológico do Mahāyāna é encarnado no personagem do Bodhisattva Avalokiteśvara.

Ao invés da presença do supremo Bodhisattva, como vimos anteriormente, um grande mantra é revelado a Sarvanīvaraṇaviṣkambhin, o șadakșarìmahāvidyā, que concede acesso a Avalokiteśvara e também ao paraíso Sukhāvatī, sua terra pura, onde o Buda Amitābha instrui todos os seres. No GKV, ele aparece no capítulo 16 na versão de 19 capítulos, 17 na versão de 20; no $K V$, a introdução do mantra forma a segunda parte do texto (segundo nirvyūha). O GKV se encerra com algumas instruções morais e um capítulo final que descreve os benefícios de atrair para si o olhar benevolente de Avalokiteśvara.

Em razão da inexistência de uma tradução do GKV publicada em língua ocidental, utilizamos inicialmente os resumos da narrativa e dos principais personagens presentes em cada capítulo fornecidos por Burnouf (2010: 234-43) e T.-Douglas (2006: 12-23), a fim de evidenciar o conteúdo geral do texto do manuscrito MAE/ USP e contextualizar a tradução integral bilíngue do capítulo 2, realizada paralelamente.

\section{Maṇdala narrativo: o metatexto}

Durante a análise do Gunakāraṇdavyūhasūtra uma terceira camada estratigráfica, aqui denominada metatexto, começou a ser vislumbrada. De fato a forma como o texto se expande, como é retrabalhado e reinserido em novas molduras narrativas, faz vislumbrar um tipo de interdiscursividade de caráter possivelmente associado aos yantra e aos mandalala, um tipo de estruturação de caráter imagético ou uma transcendência narrativa que corresponde a esses esquemas geométricos sagrados que permearam não apenas o contexto cultural indiano como também as demais sociedades sob sua influência, como o Nepal e o Tibete.

Na definição apresentada por Tucci (1969: 29), o mandala é definido como uma concepção pan-asiática, cujas ideias cosmográficas foram refletidas no esquema das cidades imperiais e na imagem ideal do reino do cakravartin, o monarca universal das tradições indianas.

O mandala delimita a superfície consagrada e a preserva da invasão das forças desagregadas simbolizadas por ciclos demoníacos. Mas ela é muito mais do que uma simples superfície consa- 
A monumentalidade discursiva no budismo indo-nepalês: uma estratigrafia das fontes escritas e iconográficas presentes no Guṇakārandavyūhasūtra

R. Museu Arq. Etn., São Paulo, n. 22, p. 3-30, 2012.

grada que se deve manter pura para fins rituais e litúrgicos. Ela é, na verdade, um cosmograma, é o universo inteiro em seu esquema essencial, em seu processo de emanação e reabsorção: o universo não apenas em sua extensão espacial inerte, mas como revolução temporal; e ambos esses aspectos, como processo vital que emana um princípio essencial e que gira em torno de um eixo central, a montanha Sumeru, o axis mundi sobre o qual se apoia o céu e que mergulha os fundamentos do misterioso subsolo (Tucci 1969: 28-29).

O esquema do mandala estende-se aos edifícios, que o budismo construiu a partir de um complexo simbolismo arquitetônico, chamados estupas. De acordo com Tucci (1969: 30), "o mesmo princípio regula a construção dos templos: todo o templo é um mandala. (...) Ela é uma projeção geométrica do mundo, o mundo reduzido ao seu esquema essencial”. Nesse sentido, os mandala fazem parte de diferentes aspectos da cultura nepalesa, são a base fundamental sobre a qual se erigiram, por exemplo, as cidades (v. Tambiah 1977), assim como os templos e seus programas iconográficos no Vale do Katmandu (v. Glowski 2002: iii). Como observou esse primeiro estudioso:

Os desenhos dos mandala, tanto simples quanto complexos, de satélites arranjados ao redor de um centro ocorrem com tamanha insistência em vários níveis do pensamento e da prática hindu-budista que somos convidados a provar sua eficácia representacional. Assim, esquemas cosmológicos de vários tipos no hinduísmo e budismo tântricos foram chamados de mandala, e.g., o cosmo constituído pelo monte Meru no centro, cercado por oceanos e cordilheiras. (...) O desenho e a disposição de monumentos arquitetônicos como Borobudur e Angkor Wat, foram chamados mandala. Em outro nível, Kautilya, no Arthaśastra usou mandala como um conceito geopolítico para discutir a configuração espacial de estados aliados e inimigos, na perspectiva de um reino específico. O corpo humano é comparado a um mandala, uma descrição que encontra ressonância nas práticas rituais e médicas. Finalmente, os desenhos de maṇdala são impressos em tecidos ou são reproduzidos nos desenhos com pó colorido de caráter transitório em numerosas ocasiões (Tambiah 1977: 69).

Nesse sentido, a hipótese surgida a partir dos dados levantados até o presente é que o Gunakāraṇ̣̂vyūhasūtra, no que tange à estrutura de seu conteúdo narrativo e personagens, pode ter sido constituído na forma de um cosmograma tridimensional, isto é, como um mandala textual.

Sabemos que a utilização de narrativas emolduradas é um procedimento retórico recorrente nas obras indianas desde a antiguidade, cujo exemplo mais conhecido é o Mahābharata. Um esquema parcial que procurou estabelecer a estrutura narrativa presente no GKV foi proposto e apresentado por T.-Douglas (2006: 54). Ocorre que seu esquema é bidimensional, com elementos retangulares representando os capítulos, inseridos nas respectivas molduras, no entanto, nem a divisão, nem a inserção desses capítulos nas molduras foram explicadas em detalhe pelo estudioso, em sua obra.

A partir do que foi compilado durante nossa análise em relação ao conteúdo narrativo, vimos que a estrutura narrativa do GKV é composta de modo concêntrico - ou seja, em termos formais, apresenta uma sucessão de diálogos que emolduram o fio condutor da narrativa. A moldura narrativa externa do GKV é representada pelo rei Jinaśrī e seu mestre Jayaśrī. Ela é seguida por uma segunda moldura, representada pelo imperador Aśoka e o mestre Upagupta. A terceira moldura é representada pelo Buda Śrīghana (Śākyamuni) e o bodhisattva Sarvanīvaraṇavișkambhin. A estrutura das molduras varia em cada capítulo, assim, podem ou não existir outras molduras internas. Nos casos em que há outras molduras, elas aparecem em capítulos específicos e são estabelecidas por cinco Budas do passado, com ou sem um interlocutor: o Buda Vipaśyin e o 
bodhisattva Mahāmati (cap. 3); o Buda Śikhin e o bodhisattva Ratnapāṇi (caps. 4 e 5); o Buda Viśvabhū e o bodhisattva Gaganagañja (caps. 6-14); o Buda Padmottara (cap. 16); e o Buda Krakucchanda (cap. 17).

Esses Budas são mencionados no Buddhavamsa, que fornece uma lista com 28 nomes, algumas versões, com 29, incluem Maitreya, o futuro Buda (v. Horner 1975). O mais antigo deles é o Buda Padmottara, que, de acordo com a lista, teria sido o $13^{\circ}$ Buda; o Buda Vipaśyin seria o $22^{\circ}$; o Buda Śikhin seria o $23^{\circ}$;

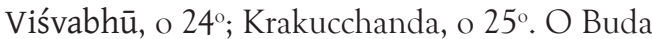
Śākyamuni chamado Śrīghana, no GKV, é o $28^{\circ}$ e último da lista.

Ao analisar as dimensões temporal e espacial envolvidas nessa obra, percebemos que essas molduras narrativas podem ser pensadas em termos de elementos geométricos que compõem um mandala tridimensional (não apenas retângulos bidimensionais como propôs T.-Douglas 2006: 54), algo que não foi proposto anteriormente por nenhum estudioso, ou mesmo utilizado como forma de análise de outras fontes literárias budistas.

Ocorre que todos esses personagens que configuram as molduras narrativas do GKV fornecem elementos temporais que criam o que podemos melhor descrever como molduras pretéritas, isto é, elas remetem o texto a eras passadas, tornando-o, assim, um cosmograma tridimensional.

Em termos temporais a cronologia é criada e, ao mesmo tempo, legitimada pela linhagem desses personagens pseudo-históricos ou míticos citados, por vezes de modo recorrente, ao longo de cada capítulo. O "presente" narrativo, ou a época em que o sūtra foi produzido, é estabelecido pela moldura externa com o rei e o mestre nepaleses. Além disso, o colofão de cada novo manuscrito do GKV o reinsere e estabelece sua linhagem, citando seu copista e local de produção. O "passado" cosmológico no GKV remonta à época dos antigos Budas até chegar ao $13^{\circ}$ deles, Padmottara.

Como havia observado acertadamente T.-Douglas (2006: 54), o uso do guruśisyaparamparā como dispositivo de ligação tem duas consequências: a primeira é que ele se coaduna bem com a ênfase recorrente no Caminho e com a compreensão de que muitos personagens no texto estão se movendo vida após vida, primeiro como seres confusos, depois estudantes, depois eventualmente mestres, bodhisattvas e finalmente Budas; a segunda é que serve para dar autoridade ao texto através do recurso não apenas do Buda mais recente, mas de Budas passados também (...). O GKV estende a cadeia de mestres e discípulos com uma moldura narrativa que segue pela Índia, com Upagupta, até o Nepal, com Jinaśrī. Enquanto o $K V$ se propõe a ser um registro fidedigno daquilo que o Buda Śākyamuni disse, o GKV, ao invés disso, propõe de modo mais plausível ser uma transmissão fiel daquilo que o Buda Śākyamuni e outros Budas disseram. Isto é, há uma mudança na forma narrativa entre os dois textos, enquanto no $K V$ a narracão das histórias internas se dá sempre na pessoa do Buda Śākyamuni, no GKV, os Budas do passado também são narradores, o que além de ser um procedimento associado à legitimação como apontou o estudioso, também remete a um claro indício de monumentalização narrativa ao se ampliar, em muitas eras, a cronologia de divindades que legitimam o texto. Amplia-se, ao mesmo tempo, a tridimensionalidade textual.

Há que se pensar, ainda, numa metamoldura, que, embora não apareça citada na obra, é a moldura formada pelos sacerdotes, monges, ou estudantes budistas que leem o GKV, algo que é feito em voz alta nos templos nepaleses até os dias atuais (v. Gellner 1992). Dessa forma, a leitura da obra é, em si mesma, uma moldura que insere o leitor-presente na última camada dessa estratigrafia cosmo-narrativa. Ao mesmo tempo, essa recitação pode ser pensada, possivelmente, nos termos da criação de um mandala sonoro.

A dimensão espacial, por outro lado, é criada pela citação de uma série de lugares associados às molduras narrativas e às diferentes regiões dos reinos do Desejo e da Forma (Kamadathu e Rupadhatu) na cosmologia budista, todas elas visitadas por Avalokiteśvara durante sua jornada para resgatar os seres sencientes. Esses locais incluem: dois infernos, a região dos pretas, dos yakșa e rākșasa, dos asura, a ilha de 
A monumentalidade discursiva no budismo indo-nepalês: uma estratigrafia das fontes escritas e iconográficas presentes no Guṇakāraṇdavyūhasūtra

R. Museu Arq. Etn., São Paulo, n. 22, p. 3-30, 2012.

Lan̉kā, a cidade de Vārāṇasī, o monastério Jetavana em Śrāvastī, a região de Magadha, o Nepal e o paraíso Sukhāvatī, do Buda Amitābha.

Assim, a espacialidade e a temporalidade narrativas observadas no GKV, por um lado, o contextualizam e o inserem na região de sua produção, mas, paralelamente, também o remetem aos inúmeros reinos da cosmologia budista. Por outro lado, esse mesmo mecanismo o torna atemporal e livre de fronteiras, o que, portanto, redimensiona sua abrangência, isto é, o monumentaliza.

Um dos indícios de monumentalização narrativa também transparece quando o Bodhisattva Avalokiteśvara assume a forma do mahāpuruṣa, que está diretamente associado ao empréstimo do mitema do hino do Rgveda, o Purușasūkta [X.10.90]. Avalokiteśvara perpassa todas as esferas espaciais e temporais, mas, ao mesmo tempo, ele também as contém. Ele encerra todos os mundos em seu próprio corpo. No esquema soteriológico budista, ele é o elo de ligação entre todos esses mundos, capaz de resgatar todos os seres e levá-los ao paraíso. Como observou Tucci (1969: 31), a primeira expressão indiana dessa intuição imaginada como um mandala é encontrada na Bṛhadāranyaka-Upanișad [II.5.15], na qual é dito: "Assim como todos os raios são enfeixados no cubo e na circunferência da roda, assim também todas as criaturas, todos os deuses, todos os mundos, todos os órgãos, todos os seres são ligados a esse Ser”.

Os vetores espaço-temporais fornecem o palco para a cosmogênese e sociomorfogênese do GKV, algo que foi estudado em termos espaciais nas cidades e na arquitetura do sul e sudeste asiático (v. Tambiah 1976, 1977; Gellner 1997), mas nunca antes em termos textuais. Assim como Tambiah (1977) e Davidson (2002), entre outros, observaram, o maṇdala é, também, um modelo social - ele retém o significado de distrito administrativo nos estados modernos de origem indiana, como a Tailândia (cf. Hanks 1975) e, como sabemos, do próprio Nepal - ou Nepal Maṇdala. A geometria das unidades sociopolíticas, inclusas aquelas encontradas no Nepal, é manifesta como um desenho recorren- te, em diferentes níveis, que o analista rotula como cosmológico, territorial, administrativo, político-econômico, mas cuja exegese acurada determina que esse desenho recorrente é "o reflexo de uma polivalência multifacetada construída sobre conceitos autóctones e da ideia tradicional de uma convergência simultânea no padrão do maṇdala" (Tambiah 1977: 91).

De qualquer forma, a concepção do mandala no qual a figura central representa a divindade suprema e à qual as figuras das quatro direções são aspectos subordinados parece um desenvolvimento natural em relação à situação política da época. Ela reflete rigorosamente a ideia de um rei supremo e central, do qual se espera que os outros governantes menores sejam projeções locais, ao invés de reis independentes (cf. Davidson (2002: 137-38). A semelhança entre os desenvolvimentos políticos e os mandala budistas é asseverada, uma vez que compreende "um sistema central ou nuclear, no entanto, os conjuntos subsidiários nas várias direções (quatro, oito, ou mais) contêm cada qual sua própria ordem interna, sendo qualquer um capaz de se tornar o centro principal se for preciso, enviando o centro anterior para a periferia”. Dessa maneira, o esoterismo budista é considerado pelo estudioso como uma metáfora imperial.

A tridimensionalidade e a monumentalização encontradas no Gunakāraṇ̣̂vyūhasūtra o insere claramente no contexto do budismo esotérico. Enquanto o KV é um sūtra Mahāyāna, o GKV é uma recriação forjada em um contexto Vajrāyana, profundamente associado aos mandala.

Esta é uma pesquisa em andamento e, neste artigo, foram abordados e discutidos os principais elementos que vêm sendo objeto de uma investigação aprofundada e cujo intuito é verificar se as modificações engendradas na transposição e na monumentalização do sūtra Mahāyāna original para o contexto Vajrāyana nepalês criou uma estrutura metanarrativa do Guṇakāraṇdavyūhasūtra, verdadeira e intencionalmente, configurada em termos de um mandala textual. 


\section{Agradecimentos}

Ao Prof. Dr. Mario Ferreira e ao Edgard S. Bikelis, pelo amplo apoio ao longo da pesquisa. Aos membros da École Française D'Extrême-Orient
- EFEO, pela prestimosa ajuda durante o estágio de pesquisa em Paris. $\mathrm{O}$ presente trabalho foi realizado com o apoio do CNPq, Conselho Nacional de Desenvolvimento Científico e Tecnológico - Brasil.

ALDROVANDI, C. E.V. Discursive monumentality in Indo-Nepalese Buddhism: a stratigraphy of the written and iconographic sources in the Gunakārandavyūhasūtra.

R. Museu Arq. Etn., São Paulo, n. 22: 3-30, 2012.

Abstract: This article presents the results of the first year of research conducted on a Buddhist Sanskrit manuscript containing the Gunakārandavyūhasūtra. This Indo-Nepalese sūtra has been investigated by means of an interdisciplinary work, combining theoretical and methodological approaches from linguistics, archeology and art history. It focuses on the stratigraphic analysis of written and iconographic sources associated with this sūtra, and aims to understand the socio-religious strategies that permeated its narrative genesis in the new milieu. The results point to a monumentalization of the original Mahāyāna sūtra while being transposed into the Buddhist esoteric context of Nepal. The sūtra acquired a narrative transcendence which transformed it into a textual mandala, a formal dimension directly associated with these sacred geometrical schemes which permeate the Nepalese cultural landscape.

Keywords: Buddhism, India, Nepal, Guṇakāraṇdavyūhasūtra, Avalokiteśvara, Iconography, Monumentality, Textual mandala.

\section{Referências bibliográficas}

\section{ALDROVANDI, C.E.V.}

2006 As exéquias do Buda Śākyamuni: morte, lamento e transcendência na iconografia indiano-budista de Gandhāra. Tese de doutorado. Museu de Arqueologia e Etnologia, USP, São Paulo, 2 vols., 977 ps.

2008 O Monge, a morte e o estupa: práxis e padrões funerários no budismo primitivo a partir das fontes arqueológicas e textuais. Revista do Museu de Arqueologia e Etnologia, São Paulo, 18: 155-182.

2009 A imagética pretérita: perspectivas teóricas sobre a arqueologia da imagem. Revista do Museu de Arqueologia e Etnologia, da Universidade de São Paulo, 19: 39-61.
BAREAU, A.

1970-71 Recherches sur la biographie du Buddha dans les Sutrapitaka et les Vinayapitaka anciens: les derniers mois, le parinirvana e les funerailles. 2 vols., Paris: EFEO.

BENTOR, Y.

1994 “Tibetan relic classification”. In: Kvaerne, P. (Ed.) Tibetan Studies (Proceedings of the Sixth Seminar of the International Association for Tibetan Studies). Oslo: 16-30.

BHATTACHARYYA, B.

1958 The Indian Buddhist Iconography: mainly based on the Sādhanamālā and Cognate tāntric texts of rituals. Calcutta, K.L. Mukhopadhaya. 
A monumentalidade discursiva no budismo indo-nepalês: uma estratigrafia das fontes escritas e iconográficas presentes no Guṇakārandavyūhasūtra

R. Museu Arq. Etn., São Paulo, n. 22, p. 3-30, 2012.

BRINKHAUS, $\mathrm{H}$.

1993 The Textual History of the Different Versions of the "Svayambhu Purana". In: Toffin, G. (Ed.) Nepal, Past and Present. CNRS, Paris: 63-71.

BROUGH, J.

1954 The Language of Buddhist Sanskrit Texts. Bulletin of the School of Oriental and African Studies, 16: 351-75.

BURNOUF, E.

2010 Introduction to the History of Indian Buddhism. [1844] Chicago: Chicago University Press.

CHANDRA, L.

1984 Buddhist iconography in Nepalese sketch-books. New Delhi: Sharada Rani.

1999 Dictionary of Buddhist Iconography. New Delhi: Aditya Prakashan. Vol.1.

2000 Dictionary of Buddhist Iconography. New Delhi: Aditya Prakashan. Vol. 2.

CHEN, S. (TRAD.)

2006 Buddha Speaks Mahayana Sublime Treasure King Sutra (Avalokitesvara-guna-karandavyuha Sutra, Tripitaka No. 1050).Translated during the Song Dynasty by Kustana Tripitaka Master TinSeekJoy. In: http:// www.e-sangha.com/alphone/1050.html ou http://www.buddhism.org/Sutras/2/ Sutras16.htm (03/07/2010).

CROSBY, K; SKILTON, A (TRAD.).

2008 The Bodhicaryavatara of Santideva. Oxford: Oxford University Press.

DAVIDSON, R.M.

2002 Indian Esoteric Buddhism: a Social History of the Tantric Movement. New York: Columbia University Press.

EDGERTON, F.

1953 Buddhist Hybrid Sanskrit Grammar and Dictionary. Vol. I: Grammar; Vol. II. Dictionary. N. Delhi: Munshiram Manoharlal Pub. (2011).

FIORIN, J.L.

2003 Polifonia textual e discursiva. In: Dialogismo, Polifonia e Intertextualidade, Barros, D.L. de P.; Fiorin, J.L. (Orgs.). São Paulo, EdUSP:.

\section{FOUCAULT, M.}

1969 A Arqueologia do Saber. Rio de Janeiro, Ed. Forense Universitária (2008).

GELLNER, D.N.

1992 Monk, Householder, and Tantric Priest: Newar Buddhism and its Hierarchy of Ritual. Cambridge Studies in Social and Cultural
Anthropology, n. 84. Cambridge: Cambridge University Press.

1997 Does symbolism 'construct an urban mesocosm'? Robert Levy's Mesocosm and the question of value consensus in Bhaktapur. International Journal of Hindu Studies, 1 (3): 541-64.

GLOWSKI, J.M.

2002 Protection, Power and Politics: an Iconographic Study of Kumari Baha Mandala in Kathmandu. PhD Dissertation, Ohio State University, Columbus.

HANKS, L.M.

1975 The Thai Social Order as Entourage and Circle. In: Skinner and Kirsch (Eds.) Change and Persistence in Thai Society. Ithaca, N.Y., Cornell University Press: 197-218.

HANDURUKANDE, R.

1967 Manicudavadana, being a Translation and Edition and Lokananda, a Transliteration and Synopsis. N. XXIV, Sacred Books of the Buddhist. Pali Text Society, London.

HORNER, I.B. (TRAD.).

1975 Minor Anthologies III - Budhavamsa and Cariyapitaka. Bristol: Pali Text Society.

HUNTINGTON, S.L.

1985 The Art of Ancient India. With contributions by John C. Huntington. New York, Weather Hill (n.ed. 1993).

KATZ, N.

1982 Buddhist Images of Human Perfection: The Arhant of the Sutta Pitaka Compared with the Bodhisattva and the Mahasiddha. Delhi, Motilal Banarsidass (2010).

KRAMRISCH, S.

1964 The Art of Nepal. Asia Society. Asia House Galerry. New York: H.N. Abrams.

KRISTEVA, J.

1967 Bakhtine, le mot, le dialogue et les romans. Critique XXIII, 239: 438-65.

LEWIS, T.T.

1996 A Chronology of Newar-Tibetan Relation in the Kathmandu Valley. In: Lienhard, S. (Ed.) Change and Continuity: Studies in the Nepalese Culture of the Kathmandu Valley, number VII, Orientalia. Turin, CESMEO: 149-166.

LI, R.

1996 The Great Tang Dynasty Record of the Western Regions. Berkeley, Numata Center for Buddhist Translation and Research. 
LIENHARD, S.

1993 Avalokiteshvara in the Wick of the NightLamp. Indo-Iranian Journal, 36: 93-104.

LOCKE, J.

1980 Karunamya: The Cult of Avalokitesvara-Matsyendranath in the Valley of Nepal. Kathmandu, Sahayogi Prakashan for Research Centre for Nepal and Asian Studies, Tribhuvan University.

1985 Buddhist Monasteries of Nepal: a survey of the bahas and bahis of the Kathmandu Valley. Kathmandu: Sahayogi Prakashan.

1987 The uposhadha Vrata of Amoghapasha Lokeshvara in Nepal. L'Ethnographie, 83: 159-89.

MALLMANN, M.T.

1967 Introduction à l'étude d'Avalokiteçvara. Paris: Presses Universitaires de France.

1975 Introduction a l'iconographie du Tantrisime boudhique. Paris: CNRS.

METTE, A.

1993 Remarks on the Tradition of the Karandavyuha. In: Mishra, K.N. (Ed.) Aspects of Buddhist Sanskrit: Proceedings of the International Symposium on the Language of Sanskrit Buddhist Texts, Oct 1-5, 1991. Sarnath, CIHTS: 510-519

METTE, A. (ED.)

1997 Die Gilgitfragment des Karandavyuha. Indica et Tibetica, vol. 29. Swisttal-Odendorf: Indica et Tibetica Verlag.

MURTHY, R.S.S.

1996 Introduction to Manuscriptology. Delhi: Sharada Pub. House.

RAJBANSHI, S.M.

1974 The evolution of Devanagari Script. Kailash Journal of Himalayan Studies, II (1\&2): 65-120.

SALOMON, R.

1999 Ancient Buddhist Scrolls from Gandhara: The British Library Kharosthi Fragments. Seatle: University of Washington Press.

SAMASRAMI, S. B. (ED.)

1873 Karanda Byuha: a Work on the Doctrine and Customs of the Buddhists. Calcutta: Dweipayara Press.

SCHOPEN, G,

1987 Burial 'ad Sanctos' and the physical presence of the Buddha in early Indian Buddhism: a study in the archaeology of religions. Religion, 17: 193-225.

1997 Bones, Stones and Buddhist Monks. Collected Papers on the Archaeological, Epigraphy and
Texts of Monastic Buddhism in India. Honolulu: University of Hawai Press.

SHARMA, P.

1990 Santideva's Bodhicharyavatara: original sanskrit text with english translation. New Delhi, Aditya Prakashan (2001).

STRONG, J. S.

1992 The Legend and Cult of Upagupta: Sanskrit Buddhism in North India and Southeast Asia. Princeton: University Press.

2004 Relics of the Buddha. Princeton: Princeton University Press.

STUDHOLME, A.

2002 The Origins of On Manupadme Hum: a Study of the Karandaryuha Sutra. Albany: State University of New York Press.

TAKAHATA, K. (ED.)

1954 Ratnamalavadana: a Garland of Precious Gems, or a collection of edifying tales told in a metrical form belonging to the Mahayana. Tokyo: Toyo Bunko.

TAMBIAH, S.J.

1976 World Conqueror and World Renouncer: a study of Buddhism and polity in Thailand against a Historical background. Cambridge Studies in Social Anthropology, n. 15. Cambridge: Cambridge University Press.

1977 The galactic polity: the structure of traditional kingdoms in southeast Asia. Annals of the New York Academy of Sciences, vol. 293, issue 1, Anthropology: 69-97.

TATELMAN, J.

1996 The Trials of Queen Yasodhara: an edition and translation of Bhadrakalpavadana chapters I-V. D. Phil. thesis, University of Oxford.

TUCCI, G.

1923 La redazione poetica del Karandavyuha. Atti della Reale Accad. Delle Scienze di Turino LVIII: 605-30.

1948 Buddhist Notes: A propos d'Avalokitesvara. Mélanges chinois e bouddhiques, 9 (1948-51): 173-220.

1969 Teoria e Prática da Mandala: com particular atenção à moderna psicologia profunda. São Paulo: Ed. Pensamento (1993).

TULADHAR-DOUGLAS, W.

1989 Sources of the Gunakarandavyuha. International Conference on "The Buddhist Heritage of Nepal Mandala", Lotus Research Center (Org.), Kathmandu, Nepal. In: http://www.aioiyama.net/lrc/papers/ cbhnm-ppr-8.htm (10/08/2010). 
A monumentalidade discursiva no budismo indo-nepalês: uma estratigrafia das fontes escritas e iconográficas presentes no Guṇakāraṇdavyūhasūtra

R. Museu Arq. Etn., São Paulo, n. 22, p. 3-30, 2012.

2006 Remaking Buddhism for Medieval Nepal. Londres: Routledge.

VAIDYA, P. L. (ED.)

1961 Avalokiteśvaraguna-Karanhdavyuha (transliteração). Darbhanga: Mithila Institute.

In: Mahayana-sutra-sangrahah. Part I - Sutran. 17. Darbhanga, The Mithila Institute: 205-308. (In: DIGITAL SANSKRIT BUDDHIST CANON: http://www. uwest.edu/sanskritcanon/dp/old/sutra/ roman/Sutra\%2019/Chapter1-2.html; 20/05/2010 )
WALLIS, G,

2001 "The Buddha Remains: Mantra in the Mañjusrimulakalpa. Journal of the International Association of Buddhist Studies, 24: 89-125.

WAYMAN, A.

1992 The Enlightenment of Vairocana. Buddhist Tradition Series, vol. 18. Delhi, Mlbd. (1998).

YIENGPRUKSAWAN, M.H.

1999 Os corpos do Buda e a virada iconográfica no budismo. In: Yoshinori, T. (Org.) A Espiritualidade Budista. São Paulo, Perspectiva, v. 2: 403-429. 